\title{
Inland swamps in South East Asia harbour hidden cladoceran diversities: species richness and the description of new paludal Chydoridae (Crustacea: Branchiopoda: Cladocera) from Southern Thailand
}

\author{
Kay VAN DAMME, ${ }^{1 *}$ Supiyanit MAIPHAE, ${ }^{2}$ Phannee SA-ARDRIT ${ }^{3}$ \\ ${ }^{1}$ Environmental Genomics Group, School of Biosciences, University of Birmingham, B15 2TT Edgbaston, Birmingham, UK; \\ ${ }^{2}$ Plankton Research Unit, The Center of Excellence for the Biodiversity in Peninsular Thailand, Prince of Songkla University, 90112 \\ Hat Yai; ${ }^{3}$ Princess Maha Chakri Sirindhorn Natural History Museum, Prince of Songkla University, 90112 Hat Yai, Thailand \\ *Corresponding author: kay.vandamme@gmail.com; k.p.vandamme@bham.ac.uk; supiyanit.m@psu.ac.th
}

\begin{abstract}
Freshwater surveys in the tropics have high potential for revealing new taxa if a wide range of habitats is included. Tropical inland swamps are ignored during most zooplankton sampling campaigns. We show that swamps harbour underestimated Cladocera diversities in South East (SE) Asia, illustrated here for Southern (S) Thailand. According to our preliminary data, based on 22 swamp sites in ten provinces, the cladoceran diversity of swamp habitats is high (about 73 taxa), i.e. a species richness of about 85\% of the cladoceran taxa recorded in $S$ Thailand. The Chydoridae are the most diverse group, about $66 \%$ of the total (48 out of 73 species), followed by the Macrothricidae (12\%; 9 species) and the Sididae (11\%; 8 species). Daphniidae only occupy a small proportion of the total species in these sites (5\%; 4 species). Besides rare taxa, the SE Asian tropical swamps contain new records, even new species. We discuss the importance of tropical swamp habitats as hotspots of cladoceran diversity, which are being destroyed through agricultural and urban development in SE Asia. As an example, we describe two new paludal species of the Chydoridae (Crustacea: Branchiopoda: Cladocera), restricted to inland swamps in $S$ Thailand. The new taxa have conspicuous morphologies within their respective genera (Karualona Dumont and Silva-Briano, 2000 and Notoalona Rajapaksa and Fernando, 1987), compared to their common sister species in the region. Karualona serrulata n.sp. is separated from congeners by i) divided denticles on the posteroventral corner of the valves and ii) single setules on the anterior face of the first limb (instead of groups of setules, as in the majority of the Aloninae). We include notes on the other, common Karualona sp. populations from $S$ Thailand. These animals show similarities with $\mathrm{K}$. iberica and $\mathrm{K}$. karua, yet belong to neither; we discuss the variability of characters in these populations and in the genus. The second new taxon, Notoalona pseudomacronyx n.sp., is a small species with a postabdomen strongly resembling that of Alona macronyx Daday, 1898, recently allocated to Celsinotum. It seems closest in morphology to an African, yet undescribed species of Notoalona. We included pictorial keys to all the species of these two chydorid genera, which have their main distribution in the circumtropics.
\end{abstract}

Key words: Chydoridae, Cladocera, swamps, Thailand, Notoalona, Karualona.

Received: January 2013. Accepted: May 2013.

\section{INTRODUCTION}

Recent efforts in the systematics of South East (SE) Asian freshwater zooplankton, have significantly increased our regional knowledge during the last 15 years, in particular in the Cladocera (Korovchinsky, 2013). Thailand is a leading example. Thai taxonomy has taken giant leaps regarding the cladocerans, from Boonsom (1984) and Sanoamuang (1998), until nowadays. Especially the last years of wide surveys and local training, have led to more realistic species identifications and diversity estimates (Maiphae et al., 2005, 2008), including the description of a number of new taxa (Kotov et al., 2005; Sinev and Kotov, 2012). Capacity building in limnology, taxonomy and biodiversity in Southern (S) [Prince of Songkhla University (PSU)] and in Northern (University of Khon Kaen, Maha Sarakham University) Thailand, have led to strong national expertise, based on first-hand experience, combined with training and knowledge transfer from international experts. This type of research increases our knowledge of the cladoceran diversity in SE Asia, and as a result, for the tropical region as a whole, forming a vital basis for regional limnological studies. However, continuous efforts and surveys are necessary, both regionally and globally (Dodson and Frey, 1991; Forró et al., 2008; Maiphae et al., 2008; Van Damme et al., 2010; Sinev and Kotov, 2012). Most recent developments in regional taxonomy show that the cladoceran diversity in several countries in SE Asia, has only just begun to receive the attention they deserve (e.g. Laos: Kotov et al., 2013; Vietnam: Sinev and Korovchinksy, 2013). Knowledge increases by revisions of known cladoceran records, which may even lead to the description of new taxa (Van Damme and Maiphae, 2013; Van Damme and Sinev, 2013) and by wider surveys with closer attention to specific habitats, as 
we will illustrate in the current manuscript. The same is true for other freshwater invertebrate groups in the region (e.g. large branchiopods) (Rogers et al., 2013).

As part of zooplankton surveys conducted under the co-ordination of the PSU from 1999 (-ongoing), we investigated the cladocerans from swamp habitats, including peat swamps, in $\mathrm{S}$ Thailand. Peat swamps in $\mathrm{S}$ Thailand, either inland swamps related to river systems or those originating from marine transgressions, have proven to be valuable habitats for freshwater biodiversity (fish: Conway and Kottelat, 2011; rotifers: Chittapun et al., 1999; Chittapun and Pholpunthin, 2001; Chittapun et al., 2002, 2003, 2007). Chittapun and Pholphuntin (2001) note for the Thai Rotifera, that peat swamps are underestimated habitats with high diversities: most of the studies sampled canals, rivers, ponds, rice fields or reservoirs, but peat-swamps, an important wetland habitat in Thailand, have largely been ignored ... peat-swamps are interesting areas for the study of rotifer biodiversity.

The situation can be similar in the Cladocera. We assume that SE Asian peat swamps are interesting habitats, yet they have been largely overlooked with regards to the Cladocera they harbour and we miss the supporting data to confirm such a hypothesis. All over the tropics, the habitat (lowland swamps) is sampled only sporadically and ideas on their cladoceran faunas are fragmentary [see Thomas (1961) for Ugandan swamps]. Even though little is known, tropical inland swamps at low altitudes have a significant potential for cladoceran biodiversity, as these habitats are rich in organic matter and macrophytes and can contain species that are adapted (or tolerant) to the dystrophic conditions. Furthermore, with increased acidity, there are fewer predators and swamps could act as useful refuges for cladocerans. The few preliminary studies that have been carried out on cladocerans in swamps of S Thailand, point towards significant diversities and are discussed in this paper (Saardrit, 2002). Lowland swamps and peat swamps are habitats that mostly occur in the lowlands of the southern portion of Thailand and are less common in the North of the country. There are several swamp types according to origin, mostly related to peat swamp forests (basinal, kerapah/watershed, brackish/marine, freshwater alluvial) (Morley, 2000). Freshwater alluvial peat swamps, in flood plains or abandoned river courses, are more permanent, other swamps can be ephemeral, therefore suitable for cladocerans, a group well adapted to temporary systems. At present, swamps are relictual habitats. The peat swamp habitat is ancient and covered much larger areas in SE Asia in the past, when also the diversity of swamp types was much larger than it is today (e.g. Miocene to Pliocene) (Morley, 2000; Morley and Morley, 2013). In this study, we comment on swamp habitats in SE Asia as an underestimated habitat for cladocerans. We describe two new Chydoridae (Crustacea: Branchiopoda: Cladocera) from tropical lowland swamp habitats, belonging to two Aloninae (Cladocera: Chydoridae) genera: Karualona Silva-Briano and Dumont, 2000 and Notoalona Rajapaksa and Fernando, 1987.

Karualona Dumont and Silva-Briano, 2000 is one of the recently separated species complexes of the lumping genus Alona Baird, 1843 (Dumont and Silva-Briano, 2000; Van Damme et al., 2010). The artificial genus Alona was traditionally used to lump most of the smaller Aloninae and it is carefully being dismantled into more natural groups (Van Damme et al., 2010). Dumont and Silva-Briano (2000) distinguished five Karualona species and a sixth was later transferred to the genus by Sinev and Hollwedel (2005). Like its sister lineage (Anthalona Van Damme, Sinev and Dumont, 2010), the genus Karualona is restricted to warm climates and it is common in the southern hemisphere, reaching as far north as the Mediterranean (Alonso and Pretus, 1989; Dumont and Silva-Briano, 2000; Van Damme and Dumont, 2010; Van Damme et al., 2011). Karualona is a genus of small chydorids that may build up large populations in well-vegetated waters and ponds in warmer regions. In fact, they are among the most common Aloninae in vegetated inland freshwaters in the tropics. Members of the genus are known to occur in dystrophic sites, like K. muelleri in Brazil (Van Damme and Dumont, 2010), habitats that are very similar to the ones sampled here, however in general, Karualona species can be found in a wide range of habitats - from small temporary pools to lakes and even in streams or rivers, entering the interstitial. As for distribution (Dumont and Silva-Briano, 2000; Sinev and Hollwedel, 2005), two species are known to occur in the New World, $K$. penuelasi Dumont and Silva-Briano, 2000 and $K$. muelleri (Richard, 1897), two in the Old World, K. socotrana Dumont and Silva-Briano, 2000 and K. iberica (Alonso and Pretus, 1989) and one in Australasia, $K$. karua (King, 1853). The former are all epigean species. Dumont and Brancelj (1994) described the first hypogean species of the genus, lacking a compound eye, K. alsafadii (Dumont and Brancelj, 1994) from Yemen.

Taxonomy of the genus is largely resolved by Dumont and Silva-Briano (2000), although uncertainties remain about the variability of characters and the limits of distribution of the two most widespread Karualona taxa, $K$. iberica (described from Spain; Alonso and Pretus, 1989) and K. karua (described from New South Wales, Australia; King, 1853; Dumont and Silva-Briano, 2000). Maiphae et al. $(2005,2008)$ identified $K$. cf. iberica from $S$ Thailand, the exact status of which remains unclear. Part of this study includes a discussion on the diagnostic characters in Karualona and an assessment of the variability of the populations in S Thailand. In addition, we describe a new species of Karualona, that was first observed and depicted by Sa-ardrit (2002) from Trang province, S Thai- 
land, but which remained undescribed. The same taxon is briefly mentioned (as Karualona sp.) from Vietnam (Sinev and Korovchinsky, 2013).

Notoalona Rajapaksa and Fernando, 1987 is a small tropical chydorid genus. According to the latest revision (Rajapaksa and Fernando, 1987), it consists of only three defined species: N. freyi Rajapaksa and Fernando, 1987, N. globulosa (Daday, 1898) (with two subspecies) and $N$. sculpta (Sars, 1901), the latter of which still needs a full description. All taxa have their distribution in the southern hemisphere (Rajapaksa and Fernando, 1987). N. globulosa, originally described from Sri Lanka, is considered circumtropical (Rajapaksa and Fernando, 1987), but we regard it as a species group here as it is uncertain whether populations outside tropical Asia belong to the same species. For example, Smirnov (2008), in his checklist of South Africa, correctly chose to keep a record of the African populations as N. cf. globulosa, after Frey (1993), which is clearly different in morphology (see Discussion). The other two species, N. sculpta and N. freyi, have been described from the New World (Rajapaksa and Fernando, 1987). The latter taxon has been mentioned from throughout the circumtropics and could also be a species group. Populations indicated as $N$. frey $i$ were reported from SE Asia, for example from S Thailand (Maiphae et al., 2005), and need examination. The same can be said for the African populations of $N$. freyi. The three species known to date are well-defined and basic limb characters have been described for N. globulosa and N. freyi (Smirnov, 1971; Rajapaksa and Fernando, 1987). Notoalona globulosa has undergone several allocations, between Alona and Notoalona (e.g. under Indialona in Smirnov, 1971), but is housed and stable since Rajapaksa and Fernando (1987) (Kotov, 2000; Van Damme et al., 2010). Taxonomy is resolved and because of the peculiar morphology of Notoalona, there has been no confusion of any of these species with other genera since the revision in 1987.

In this study, we describe and discuss the morphology of a new species of Karualona and of Notoalona from inland swamps in S Thailand. We include comments on the complexity of Karualona phenotypes in this region $(K$. cf. iberica and $K$. cf. karua) and we discuss the importance of inland, lowland swamp habitats in the regional study of Cladocera.

\section{METHODS}

We analysed wet samples, slides and unpublished records on cladocerans from lowland (no high altitude) swamp habitats from 1999-2000 (with additional samples from 2010-2012), kept at the Center for Excellence for the Biodiversity in Peninsular Thailand at the PSU, Thailand. Samples (e.g. for the two new species, from Natam peat swamp, Trang province, the swamp at Ratchaprapa dam, Suratthani province and Kangkao peat swamp,
Songkhla province) were taken using a conical plankton net, mesh size $60 \mu \mathrm{m}$. Specimens were either selected from the samples or removed from slides under a binocular stereomicroscope and subsequently placed on slides in a 1:2 glycerol-formaldehyde mixture. Drawings were made from complete and dissected specimens, using a camera lucida connected with a compound microscope (Olympus CX31; Olympus, Tokyo, Japan). We used a scanning electron microscope (SEM) at PSU for studying the fine morphology of the species. Samples were prepared using the following method; field samples were preserved with 95\% ethanol. After sorting and cleaning (by rinsing), specimens were dehydrated (complete and dissected specimens) in a series of increasing alcohol concentrations (10, 30, 50, 70, 90, 95, 96 and 100\%) (Van Damme and Maiphae, 2013). Each dehydration series was done twice, each time $c a .30 \mathrm{~min}$. Subsequently the specimens were handled through critical point drying (CPD), mounted on $10 \mathrm{~mm}$ stubs and gold-coated. Scanning electron microscope micrographs were then taken using a SEM (JEOL JSM-5800LV). Type material is deposited and kept at the Princess Maha Chakri Sirindhorn Natural History Museum, Faculty of Science (PSUNHM), Thailand. We did not apply any statistical methods to the data, as the samples were not taken in a standardised way, nor with additional measurements. However, we believe that the data, simply presented by presence of species from swamp habitats, clearly support the main hypothesis that swamps harbour high cladoceran richness.

\section{RESULTS}

\section{Taxonomical account}

\section{Notoalona pseudomacronyx $\mathrm{n} . \mathrm{sp}$.}

Type locality: Natam swamp, Trang province, western coast of S Thailand, coordinates $07^{\circ} 37.029^{\prime} \mathrm{N}$, 99³3.628'E.

Etymology: the epithet pseudomacronyx refers to the postabdomen of this new species, which resembles the postabdomen of Alona macronyx Daday, 1898, a species now allocated to the genus Celsinotum Frey, 1999 (Sinev and Kotov, 2012).

Material: we examined ten adult specimens, of which several were used for SEM; from the others, the type specimens below were selected. All type material deposited at the PSUNHM, Faculty of Science, PSU, Thailand. HOLOTYPE: an adult parthenogenetic female in a sealed $70 \%$ ethanol (with a drop of glycerol) tube from Natam swamp, Trang province, western coast of S Thailand, coordinates $07^{\circ} 37.029^{\prime} \mathrm{N}, 9^{\circ} 33.628^{\prime} \mathrm{E}$, collected by K. Van Damme, S. Maiphae and P. Sa-ardrit, 9.IV.2000. Accession number PSUZC-PK1001-01, labelled as: Notoalona pseudomacronyx sp.nov., 1 parthenogenetic female from Natam swamp, Trang province, S Thailand HOLOTYPE. 
PARATYPES: one complete adult parthenogenetic female, in slide, same data as holotype. Accession number PSUZC-PK1001-03. One dissected adult parthenogenetic female, same data as holotype. Accession number: PSUZC-PK1001-04. Five additional adult parthenogenetic females (with same data as holotype) in a tube with 70\% ethanol, deposited under PSUZC-PK1001-02.

Description of the adult parthenogenetic female: Habitus (Figs. 1A, 1B and 2A). Small species, average $0.3 \mathrm{~mm}$, ranging from 0.28 to $0.31 \mathrm{~mm}$. Ornamentation see under Carapace below. Body 1.3 times as long as high and more globular than oval in dorsal and lateral views, with convex curved dorsum (Fig. 1A). In lateral view, the ventral margin of the valves is not straight but with a depression, the deepest point of which is situated at about one third (from frontal margin) of the total carapace length (Fig. 1A and 1B). The posterior margin of the valves is straight to moderately convex in lateral view, the posteroventral corner round with several (two to five) clusters of thicker setules (Fig. 2C), that may be merged into conical denticles (Fig. 1G). Dorsal keel absent.

Head. Ocellus smaller than eye (diameter of eye about 2.5 times the diameter of the ocellus), equidistant between latter and rostrum (Fig. 1C). Rostrum clearly separate from the rest of the headshield by two lateral incisions followed by abrupt lateral expansion of the headshield [lateral notches in Rajapaksa and Fernando (1987)] (Figs. 1C, 1F and 2B). Rostrum otherwise with widely blunt and straight apex (Figs. 1F and 2B). Antennular corms not reaching apex of rostrum, their aesthetascs projecting half their lengths beyond it, oriented straight forward (Fig. 1F). Two main elongated head pores (Fig. 1D) of the same size in a V-shaped arrangement, and no lateral pores (typical for the genus). Each pore is about four times as long as wide.

Carapace. Transparent. Ornamentation a faint longitudinal striation of wide striae (Fig. 2A). Under light microscope, an internal pattern perpendicular to the longitudinal striae becomes visible, which should not be confused with the carapace striation (Fig. 1B). Hexagonal patterns with transverse connections are absent. Marginal setae 42-70, differentiated into two main groups: a longer anterior group that decreases in length towards the ventral embayment, and a median-posterior group with shorter sized setae. All the marginal setae are implanted on submarginally on the inside of the valve, not marginally (Fig. 2A). The marginal setae are fine, with longer setules on their posterior faces. Setae decreasing in size towards the posteroventral corner, followed by clusters of thicker spinules, merging into two to three denticles (Figs. $1 \mathrm{G}$ and 2C).

Labrum (Figs. 1E and 2B). Labral keel in lateral view with concave margin and pointed tip, with serrulation in lower half. The serrulation is expressed in one to four denticles, mostly three, the feature is highly variable and the lower part of the labral keel margin may just be irregular with only one tooth (Fig. 2B). The labral keel has no ventral setules (Figs. 1E and 2B). Antennules (Fig. 1F and $1 \mathrm{H})$. Short and stout, about 2.5 times as long as wide, with sensory seta implanted about halfway from the apex, on a projection. No setules on the antennular corm observed. Aesthetascs all of same length and about the same length of the antennular body. Second antennae (Figs. 1I and 2B). Coxal setae long (Fig. 1J). Coxal spine not seen. Spinal formula 001/101, setal formula 113/003. First endopod seta on the antenna short, reaching not beyond the second segment (Fig. 1I). No spines on endopod, only groups of small conical spinules (Fig. 2B). Spine on the first and second exopod segments minute, spine on the first segment larger and more conical than on second segment (Fig. 2B); main terminal spines on endo- and exopod short and conical, less than a fourth in length of the ultimate antennal segments (Fig. 1I). Terminal setae fine and all of similar thickness.

Postabdomen (Figs. 1K-N and 2D). Widest at the postanal projection. Dorso-distal embayment near base of terminal claw rather deep and the dorso-distal angle projecting. Length about two and a half times as long as wide, strongly tapering distally. Ventral margin straight, longer than anal and postanal margin together. Anal and postanal margin of the same length. Anal margin strongly concave, postanal corner strongly angular, postanal margin straight, distal margin protruding. Preanal angle well developed and angular (postanal corner forms an angle of about $145^{\circ}$. Seven to nine small postanal denticle groups, each group of two to three small conical teeth (Figs. 1K, 1L and 2D). Eight to ten short postanal teeth with small anterior spines at the base. Lateral fascicles six to eight groups in postanal portion, the distalmost groups consisting of two to four spinules in each group, parallel to each other. The four distal groups are larger, with distalmost spine very long and thick, reaching over the dorsal margin (Figs. 1N and 2D). Other lateral fascicles (not the four most distal ones) have more spinules in each group (up to ten) and not a conspicuously thicker distal spine (Fig. 2D). The lateral fascicles and marginal denticles continue in groups on the anal margin, the lateral fascicles forming at least two rows (Fig. 2D), marginal denticles in about two to three groups of each four to six teeth. Terminal claw (tc) (Fig. 1L and 1M). Long and slender, about one to one and half as long as anal margin, straight in proximal two thirds, curved in the last third. Strong proximal pecten and strong ventral pecten present. Fine and long basal spine, at least two times as long as claw width at base, at least one quarter of tc length (Fig. 1K), and with strong, long basal spinules (Fig. 1M).

First maxilla not investigated. Five pairs of limbs.

First limb (Figs. 2E, 2F and 3A-F). Epipodite not seen. First endite with two marginal setae and one thick anterior modified seta, second endite with three setae of which two 


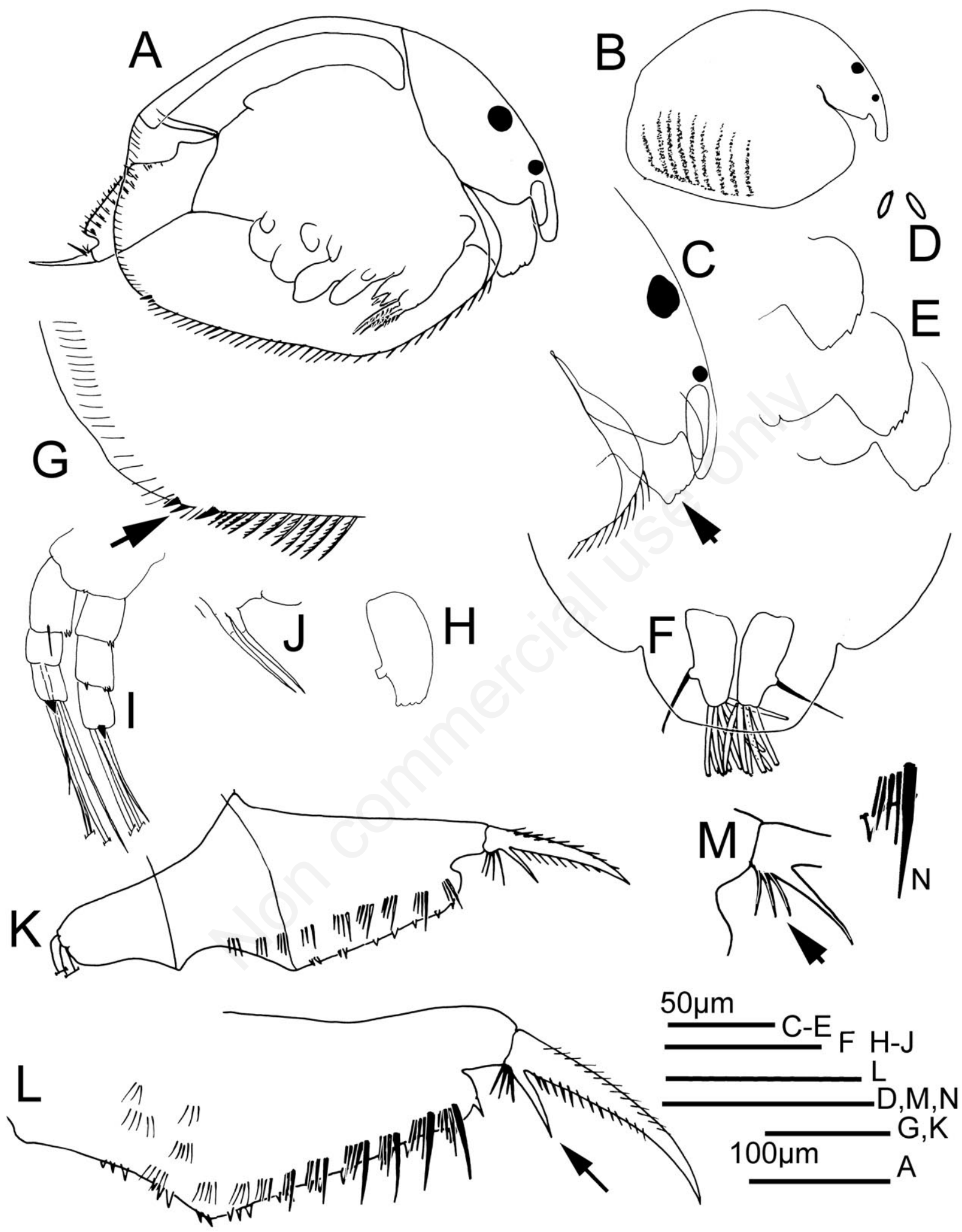

Fig. 1. Notoalona pseudomacronyx n.sp., adult parthenogenetic females from Natam swamp, Trang province, Southern Thailand, collected in April 2000 by K. Van Damme, S. Maiphae and P. Sa-ardrit. A,B) Habitus, lateral view; C) head, lateral view (arrow points to labral keel indentation); D) main head pores; E) labral keel, variation; F) rostrum in dorsal view with first antennae; G) posteroventral corner of valves (arrow points at denticles); H) antennular body (setae and aesthetascs not shown); I) second antenna; J) basal setae on second antenna; K,L) postabdomen, complete (arrow indicates long basal spine); M) basal spine and basal spinules on terminal claw (arrow indicates long basal spinules); N) lateral fascicle (second distalmost group) and marginal denticle. 

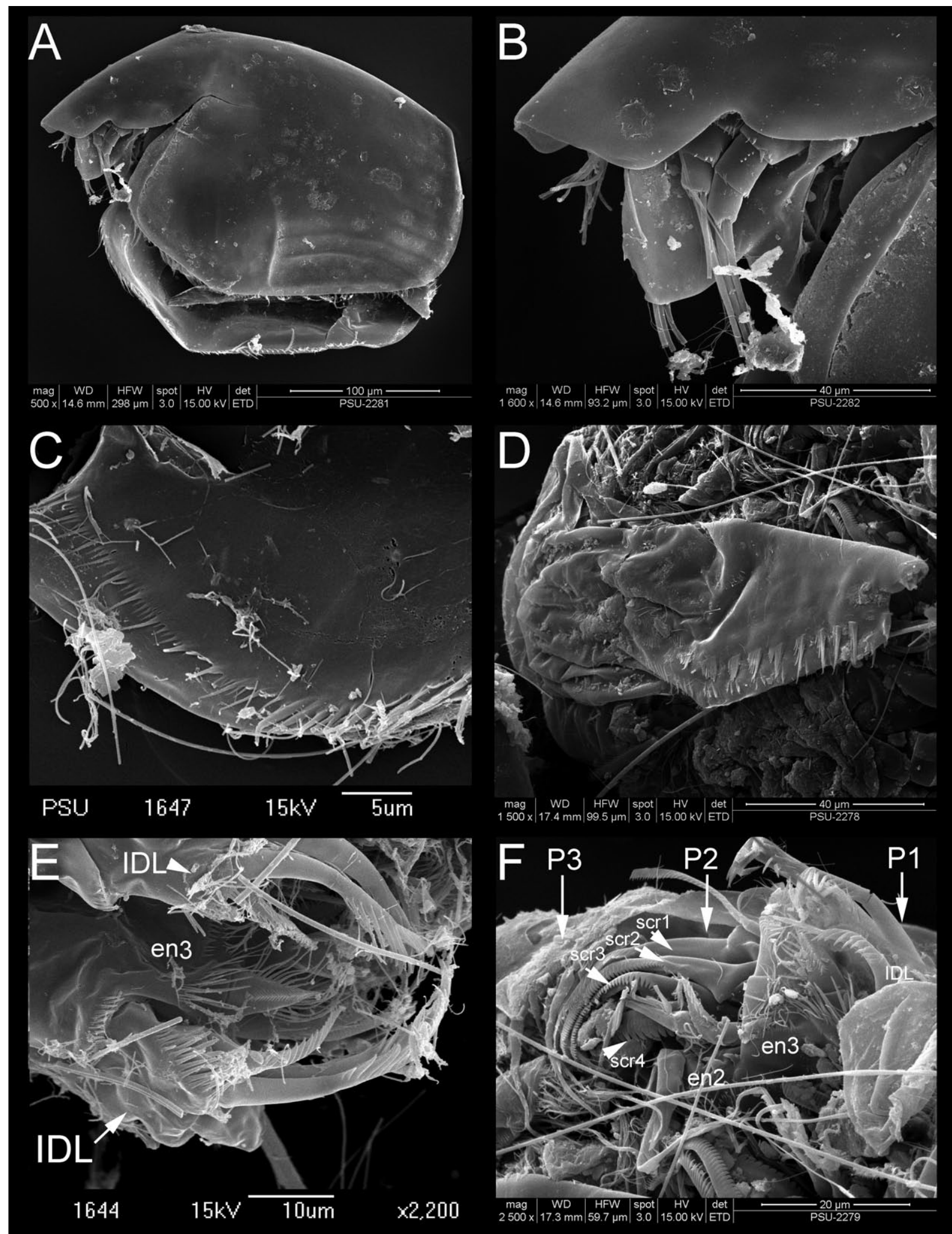

Fig. 2. Notoalona pseudomacronyx n.sp., scanning electron microscopy of adult parthenogenetic females from Natam swamp, Trang province, Southern Thailand, collected in April 2000 by K. Van Damme, S. Maiphae and P. Sa-ardrit. A) Habitus, lateral view; B) head, lateral view showing rostrum, labral keel and second antenna; C) posteroventral corner of valves, inner view; D) postabdomen (no terminal claw); E) first limb, inner distal lobe setae; F) first, second and third limb in situ, ventro-lateral view. en=endite; IDL=inner distal lobe; $\mathrm{P} 1-3=$ limbs 1 to 3; scr=scraper. 
longer and two additional small anterior elements, third endite with four setae of which two broadly conical (Fig. 3A and 3C); anterior elements on endites 1-2 present (Fig. 3B), the element on the first endite as typical for the genus, with broad, bent blunt spoon-like apex with small serrulation and a curved setule (or merged setules) bent over it (Fig. $3 \mathrm{~B})$. Anterior elements on the second endite just two reduced small conical setae (Figs. 2F and 3C). Thickest seta on third endite (Fig. 3C) with thick conical setules forming a crown around the middle. Outer distal lobe (ODL) with one slender seta, with short stout setules and longer than largest inner distal lobe (IDL) seta (Figs. 2E and 3D); IDL with three setae, decreasing gradually in length; armature of all IDL setae consists of a strong setulation in distal half (Figs. 2E and 3D). No accessory seta present. No anterior setule groups on the limb corm (Fig. 3E) and a single gnathobase seta on a projection (Fig. 3E and 3F). Ejector hooks relatively short, subequal (Fig. 3C).

Second limb (Figs. 2F and 3G). Exopodite short and broad, oval to round, lacking a seta but with minute short setules. Endites with eight scrapers gradually decreasing in size towards gnathobase, eighth scraper shortest (Fig. $3 G)$. First two scrapers slender and finely setulated, second scraper slightly longer than first, followed by third scraper of similar length and slenderness, scrapers four to eight much stouter, shorter and thicker; scrapers four to eight with conspicuously stronger teeth (see scraper four vs three in Fig. 2F); gnathobasic brush small and round, implanted with short setules. Gnathobase with a small sensillum and three modified elements on a joint elevated basis, of which first a short bent seta, second a plump seta and third a short seta; filter comb (Fig. 3G) with seven setae of which only the first shorter by half the second.

Third limb (Fig. 3H-L). Pre-epipodite and epipodite not seen; exopodite (Fig. 3H and 3I) with rectangular corm and seven large marginal setae in $2+5$ arrangement; first exopodite seta twice as long as second; third exopodite seta about two times as long as sixth exopodite seta, fourth and fifth setae very short and of equal size (about a third of sixth seta), seventh seta even shorter and bent away from the sixth seta (Fig. 3H and 3I). All setae plumose, sixth with shorter setules. External endite (Fig. 3J) with three setae (1'-3' in Fig. 3J) of which first two longer, with short setules in distal half, third (3'in Fig. 3J) shorter by half and with long setules; four fine plumose setae on inner side (1"4 " in Fig. 3J) of same length; one naked element and four small naked setae on internal endite (Fig. 3K) preceding gnathobase; gnathobase (Fig. 3L) with a bottle-shaped sensillum and bent plumose seta with two naked elements at its base (Fig. 3L). Filter comb with seven setae (Fig. 3J).

Fourth limb (Fig. 3M and 3N). Pre-epipodite oval, epipodite elongate with broad projection. Exopodite quadrangular with six marginal plumose setae (Fig. 3M) in 3+3 arrangement; first three exopodite setae similar in size, fourth seta just shorter than preceding seta; fifth and sixth setae not more narrow than the rest; sixth seta about same length of fifth, sixth bent outwards. Setae four to six are on a separate small projection of the exopodite. Endite (Fig. 3N) with marginal row of four setae of similar morphology, gradually decreasing in size towards the gnathobase. The first seta ( 1 ' in Fig. 3J) without strong setulation, three following setae (2"-4" in Fig. 3J) also slender with thicker basis and unilaterally armed with thick setules. One elongate marginal naked sensillum (Fig. 3N); gnathobase with one long setae, and naked projection at its base; on the inner side, three long plumose setae (1"-3" in Fig. 3N) of similar length and a filter comb with five slender setae (a-e in Fig. 3N).

Fifth limb (Fig. $3 \mathrm{O}$ and 3P). Pre-epipodite elongate, armed with long setules; epipodite round with long fingerlike projection, reaching centre of exopodite. Exopodite (Fig. 3O) shape oval, about two times as long as wide, with straight to moderately concave setulated margin continuing in convex rounded margin towards inner lobe; three exopodite setae of similar length gradually decreasing in size, first (dorsal) longest, longer than the exopodite width; fourth seta absent (Fig. 3P, arrow); inner portion of limb (Fig. 3O) with wide oval inner lobe with long apical setules; two endite setae (1'-2' in Fig. 3O) of which first not longer than inner lobe; second endite seta (2') about half as long. No element behind the second endite seta observed and no gnathobasic elements found.

Sixth limb. Absent.

Ephippial female, ephippium and male: unknown.

Differential diagnosis: Notoalona pseudomacronyx n.sp. can be recognised within the genus by its peculiar postabdomen (tapering distally and with long basal spine on the terminal claw). Basal spine at least twice the length of terminal claw at base and one third to one quarter of the full terminal claw length (in Notoalona globulosa s.str., this is not longer than the base of the claw). Strong lateral notch in the headshield and a truncated rostrum. The species is also very small: total length no more than $0.3 \mathrm{~mm}$, mostly $0.285 \mathrm{~mm}$ ( N. globulosa is up to 0.38 $\mathrm{mm})$. Mostly denticles in the posteroventral corner, not groups of setules. Found to coexist with two other $\mathrm{No}$ toalona species in the type locality, Natam swamp ( $N$. globulosa and $N$. cf. freyi). It differs from Notoalona sp. from Africa (Rajapaksa and Fernando, 1987) in longer basal spinules on the basal spine, seven to ten lateral fascicle groups on the postabdomen, a straight postanal margin and the smaller body size (the African taxon is up to $0.44 \mathrm{~mm}$ ). See also the key to species. It differs from Celsinotum macronyx, which has a superficially similar postabdomen, in the absence of a dorsal keel and in the headpores, (among many other differences between Celsinotum and Notoalona) [Sinev and Kotov (2012) for a redescription of C. macronyx]. 


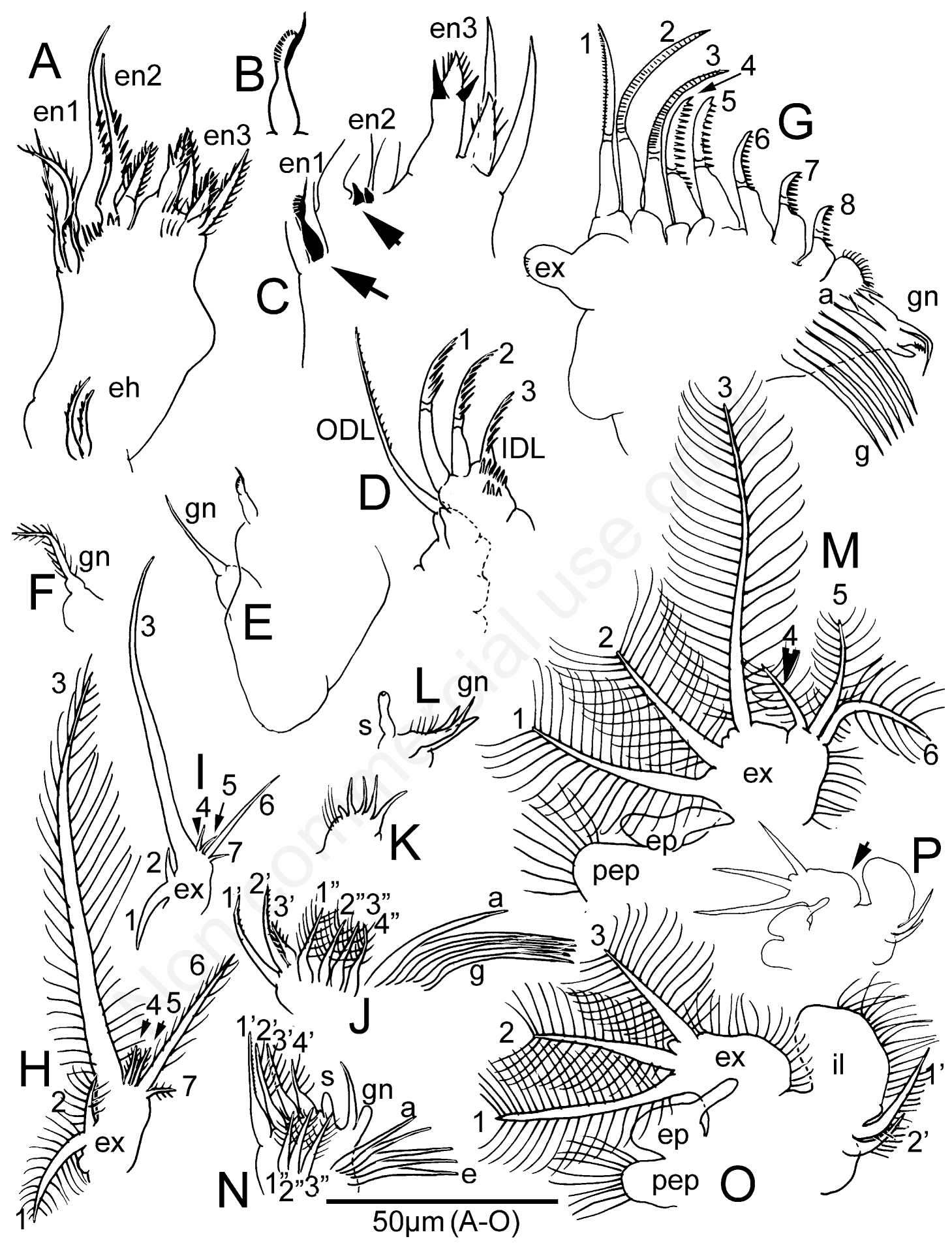

Fig. 3. Notoalona pseudomacronyx n.sp., adult parthenogenetic females from Natam swamp, Trang province, Southern Thailand, collected in April 2000 by K. Van Damme, S. Maiphae and P. Sa-ardrit. A) First limb, anterior view; B) modified anterior seta of first endite; C) first limb, anterior view (detail) with arrows showing anterior structures; D) first limb, inner (setae 1-3) and outer distal lobe; E,F) first limb, gnathobase; G) second limb (scrapers 1-8); H) third limb, exopodite (exopodite setae 1-7); I) third limb, exopodite (setulation omitted; exopodite setae 1-7); J) third limb, endite, inner portion with endite setae 1'-3' and 1"-4"; filter comb setae numbered a-g; K) third limb, endite, outer portion; L) third limb, gnathobase; M) fourth limb, exopodite (exopodite setae 1-6); N) fourth limb, endite (flaming torch setae 1'-4', inner endite setae 1'-3"; filter comb setae numbered a-e); O) fifth limb (exopodite setae 1-3; inner setae 1'-2'); P) fifth limb, setulation omitted (arrow points at position of absent seta). en=endite; eh=ejector hooks; IDL=inner distal lobe; ODL=outer distal lobe; gn=gnathobase; ex=exopodite; a-e/g= numbering filter comb setae; s=sensillum; pep=pre-epipodite; ep=epipodite; il=inner lobe. 
Distribution and biology: except for the present record, a single locality in S Thailand, this species has not been reported nor depicted before. Found in a shallow dystrophic swamp (Natam swamp) in Trang province, between Salvinia cucullata. It could be a S Thailand endemic, but the habitat in SE Asia should be widely sampled.

\section{Karualona serrulata n.sp.}

Karualona sp. in Sa-ardrit (2002); Sinev and Korovchinsky (2013) (Fig. 2H-K)

Type locality: swamp at Ratchaprapa dam, Suratthani province, eastern coast of S Thailand; $08^{\circ} 58.074^{\prime} \mathrm{N}$, 098 49.056’'E.

Etymology: the epithet serrulata refers to the serrulate margin at the posteroventral corner of the valves, a unique and easily recognisable feature for this species.

Type material: all type material deposited at the PSUNHM, Faculty of Science, Prince of Songkla University, Thailand. HOLOTYPE: an adult parthenogenetic female in a sealed $70 \%$ ethanol (with a drop of glycerol) tube from a swamp at Ratchaprapa dam, Suratthani province, eastern coast of S Thailand; $08^{\circ} 58.074^{\prime} \mathrm{N}, 098^{\circ} 49.056^{\prime} \mathrm{E}$; collected by S. Maiphae and S. Fangcholjit, 19.IV.2010. Accession number PSUZC-PK1002-01, labelled as Karualona serrulata sp.nov., one parthenogenetic female from swamp at Ratchaprapa dam, Suratthani province, S Thailand HOLOTYPE. PARATYPES: one complete adult parthenogenetic female, in slide, same data as holotype. Accession number PSUZC-PK1002-02. Six specimens, in slides, dissected and undissected adult parthenogenetic females, same data as holotype. Accession numbers PSUZCPK1002-03 to PSUZC-PK1002-08.

Additional material: five adult parthenogenetic females from Natam swamp, Trang province, western coast of S Thailand; $07^{\circ} 37.029^{\prime} \mathrm{N}, 99^{\circ} 33.628^{\prime} \mathrm{E}$; collected by K. Van Damme, S. Maiphae and P. Sa-ardrit, April 2000. Ten adult parthenogenetic females from the type locality, the swamp at Ratchaprapa dam, Suratthani province, eastern coast of S Thailand; $08^{\circ} 58.074^{\prime} \mathrm{N}, 098^{\circ} 49.056^{\prime} \mathrm{E}$; collected by S. Maiphae and S. Fangcholjit, 19.IV.2010. Two adult parthenogenetic females from Kangkao peat swamp, Songkhla province, eastern coast of $\mathrm{S}$ Thailand; $06^{\circ} 55.21^{\prime} \mathrm{N}, 100^{\circ} 27.352^{\prime} \mathrm{E}$; collected by S. Maiphae and K. Kaiseng, 10.VII.2012.

Description of the adult parthenogenetic female: Habitus (Figs. 4A, 4B, 5A and 6A). Average length 0.35 $\mathrm{mm}$, ranging from 0.3 to $0.38 \mathrm{~mm}$. Ornamentation - see under Carapace below. Body 1.6 times as long as high and more elongate than globular in lateral view, with moderately convex dorsum with highest point near the middle (Figs. 4A, 4B and 5A). In lateral view, the ventral margin of the valves has its deepest point at about one third (from frontal margin) of the total carapace length (Fig. 4B), this point rather angular. The posterior margin of the valves is convex in lateral view, with clear embayment near the posteroventral corner (Fig. 5C). Posteroventral corner round with serrulate margin, about five to eight teeth, each subdivided into three to five (mostly) divisions (Figs. 4D, $4 \mathrm{E}, 5 \mathrm{C}, 6 \mathrm{E}$, and $6 \mathrm{~F}$ ). Posteroventral valve teeth are very fine (Fig. 6E and 6F). Dorsal keel absent.

Head. Ocellus same (Fig. 5A) or smaller than eye (diameter of eye about 1.5 times the diameter of the ocellus) (Fig. 4A), equidistant between latter and rostrum (Figs. $4 \mathrm{~A}$ and $5 \mathrm{~A}$ ) or just closer to the eye (Fig. 4B). Rostrum protruding and blunt (Figs. 4H and 7C). Antennular bodies not reaching apex of rostrum, their aesthetascs projecting half their lengths beyond it, oriented straight forward (Figs. 4A and 6B).

Headshield about 1.35 times as long as broad, with two main connected headpores and two lateral small pores (Figs. 4G, 4I, 6G, 7C, and 7D). Main headpores about 1.4 interpore distance (distance between the two main pores) from posterior margin of headshield (Figs. 4I and 7D), lateral pores are about 1.0-1.2 times the interpore distance from the midline.

Carapace. Colorless to brownish. Ornamentation a faint longitudinal striation of wide striae (Figs. 4A, 4B, $5 \mathrm{~A}, 6 \mathrm{~A}, 7 \mathrm{~A}, 7 \mathrm{~B})$. Hexagonal patterns with transverse connections not present, yet minute, close striation is present on the carapace (Figs. 4C and 7A) as well as on the headshield (Fig. 4I), sometimes absent (Fig. 6G). Marginal setae 48-54, differentiated into three groups, each covering about a third of the ventral carapace margin: a longer anterior group (Fig. 4C) that reaches to the ventral embayment of the valves, a median short group around the middle with shorter sized setae and a third posterior group with setae intermediate in size between the first and second group (Fig. 4C). All the marginal setae are implanted marginally on the valve. The marginal setae are fine, with longer setules on their posterior faces. Posteroventral corner as described above, with serrulate margin consisting of divided teeth (Figs. 4D, 4E, 5C, 6E, and 6F) and with strong embayment (Fig. 5C).

Labrum (Fig. 4F). Labral keel in lateral view with concave margin and irregular tip. Single blunt denticle present in the labral keel (proximally) (Fig. 4F). No ventral setules on labral keel, and a strong lateral projection is present as typical in the genus. Irregular ventral portion of the tip rather abruptly breaking the smoothly curved keel margin. Antennules (Figs. 4K, 5B and 6B). Long and curved, about 3.0-3.5 times as long as wide, with sensory seta implanted between half and about one third from the apex, on a small projection (Fig. 4K). At least three rows of fine setules on the antennular body (Fig. 5B). Aesthetascs long, most as long as the antennular body, of different lengths. Longest aesthetasc longer than the antennular body. Sensory seta short, not reaching beyond the apex of the antennular body. 


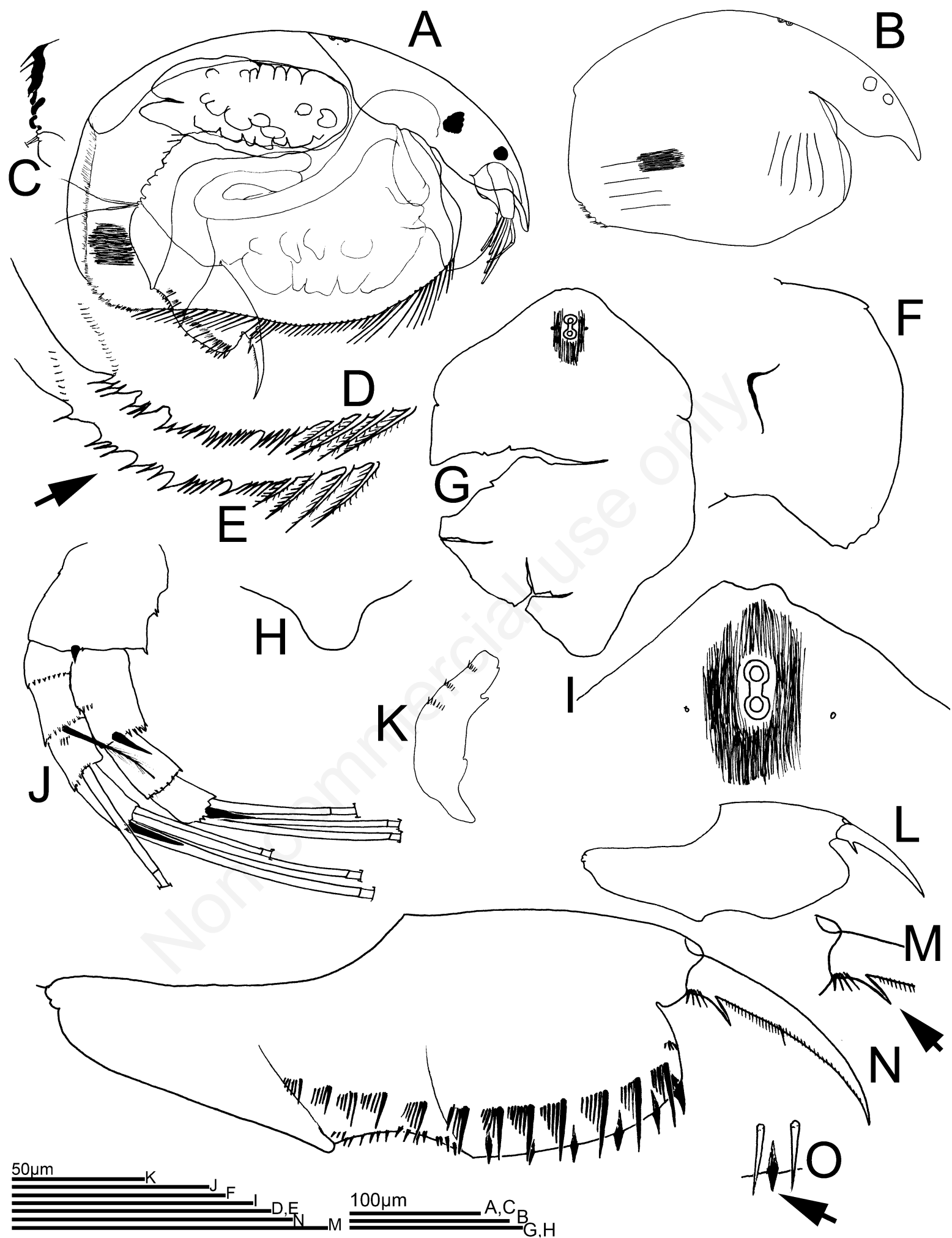

Fig. 4. Karualona serrulata $n$.sp., adult parthenogenetic females from swamp at Ratchaprapa dam, Suratthani province, Southern Thailand, collected in April 2010 by S. Maiphae and S. Fangcholjit. A,B) Habitus, lateral view; C) sclerotisation of dorsodistal portion of abdomen; D,E) posteroventral corner of valves (arrow points at serrulation of the margin); F) labral keel, lateral view; G) headshield; H) rostrum; I) posterior margin of headshield and head pores; J) second antenna; K) first antenna (without aesthetascs); L) postabdomen (contours); M) basal spine on terminal claw (arrow points at well-developed basal spine); N) postabdomen, complete; O) lateral fascicles (only distalmost spine shown for length) and marginal denticle in postanal portion, detail (arrow points at conical marginal denticle). 
Second antennae (Figs. 4J, 6C and 7E). Coxal setae not observed. Coxal spine short, conical (Figs. 6C and 7E). Spinal formula 001/101, setal formula 113/003. First endopod seta short, not reaching beyond the ultimate endopod segment (Figs. 4J and 7E). No spines on endopod, only groups of small spinules (Fig. 6C). Spine on the first and third exopod segments well developed, spine on the first segment reaching beyond half of the second segment (Figs. 4J and 7E); terminal spines on endo- and exopod long and slender, about same length of the ultimate segments they are implanted on (Fig. 6C). Terminal setae thick and of different lengths (broken off at segment in Fig. 6C, showing clear differences in lengths); terminal endopod setae slightly thicker than exopod setae (Fig. 7E).

Postabdomen (Figs. 4L-O, 5D, 5E and 6D). Deepest at the preanal projection (variable). Deep dorso-distal embayment near the base of terminal claw (Figs. 4L, 4N and $5 \mathrm{E})$, the dorso-distal angle projecting. Postanal margin rather straight and tapering distally (Figs. 4L and 5D). Length about two to two and a half times as long as wide. Ventral margin straight to moderately curved, about as long as anal and postanal margin together. Postanal margin longer than anal margin (about 1.2-1.3 times as long). Anal margin concave, preanal corner angular, postanal margin straight, distal margin protruding. Postanal angle mostly distinct (Figs. 4L, 4N and 5D). Six to eight strong stout postanal marginal denticles (Figs. 4N, 4O, 5E and $6 \mathrm{D})$, sometimes accompanied by a second smaller denticle (Fig. 5E). Lateral fascicles eight to ten groups in postanal portion, the distalmost groups with about eight to ten spinules per group, parallel to each other, distalmost spinule strongly developed (Figs. 4N and 5E). Longest, distal spines in lateral fascicles do not reach beyond the marginal denticles (or just beyond) (Fig. 4O). The lateral fascicles and marginal denticles continue on the anal margin, the lateral fascicles forming one row of about five groups (Figs. 4N and 5E), marginal denticles in about two to three groups of each four-five or more teeth. Terminal claw (Figs. 4M, 4N, 5E and 6D). About 1.5 times as long as anal margin, rather straight. Proximal and distal dorsal pecten moderate, length of spinules not reaching beyond the length of basal spine (Fig. 6D). Well developed and thick basal spine (Figs. 4M and 6D),about as thick as claw width at base, and about one quarter of tc length (Fig. 6D), with strong basal spinules (Figs. 4M and 6D).

First maxilla not investigated. Five pairs of limbs.

First limb (Fig. 8A-D). Epipodite not seen. First endite with one posterior and two marginal setae, second endite with three setae of which two longer and with typical armature, third endite with four setae of similar length, of which one broadly conical and twice as thick as the others (Fig. 8A); anterior elements on ens absent. Thickest seta on third endite (Fig. 8B) with thick conical setules forming a crown around the middle, and unilaterally armed with strong denticles in second half. Outer distal lobe with one slender seta, unilaterally armed with fine setules in distal half and longer than longest IDL seta (Fig. 8D); IDL with three setae, of which the smallest less than half the other two, which are of similar length (Fig. 8D and 8E); armature of two longest IDL setae consists of a long setules in distal half (Fig. 8D and 8E). No accessory seta. Anterior setules on first limb not in groups, but a series of six to seven single long setules (Fig. 8A and 8C), decreasing in size ventrally (Fig. 8C). Gnathobase projection not observed. Ejector hooks relatively short and of similar length (Fig. 8A).

Second limb (Fig. 8F and 8G). Exopodite short and broad, lacking a seta but with minute short setules on its apex. Endites with eight scrapers gradually decreasing in size towards gnathobase, eighth scraper shortest (Fig. 8F). First two scrapers slender and finely setulated, second scraper slightly shorter than first, followed by third scraper which is markedly shorter and thicker, fourth and fifth of similar size as third and sixth much shorter, gradually stepwise shortening seventh and eighth scrapers (Fig 8 F). Projection near the basis of first scraper (1' in Fig. $8 \mathrm{G}$ ) and second scraper (2' in Fig. 8F); gnathobasic brush small and triangular, implanted with short setules. Gnathobase with a small sensillum and three typical modified gnathobasic elements; filter comb (Fig. 8F, a-g) with seven setae of which the first two shorter by less than half the third filter comb seta.

Third limb (Fig. 8H-J). Pre-epipodite and epipodite not observed; exopodite (Fig. $8 \mathrm{H}$ ) with quadrangular corm and six setae in $2+5$ arrangement; first exopodite seta nearly twice as long as second, both plumose; third exopodite seta about two times as long as fifth exopodite seta and sparsely implanted with fine setules, fourth and fifth setae similar lengths, fifth implanted with setules only in distal two thirds, sixth seta even rather thinner and shorter than fourth or fifth setae (Fig. 8H). External endite (Fig. 8I) with three setae (1'-3' in Fig. 8I) of which first two longer, with short stout setules in distal half, third (3'in Fig. 8I) shorter by half and with long setules; four fine plumose setae on inner side (1"-4" in Fig. 8I) increasing in size towards filter comb and with rather thick basis; one naked element and four small naked setae on internal endite (Fig. 8I, above) preceding gnathobase; gnathobase (Fig. 8J) with a bottle-shaped sensillum (s in Fig. 8J) and bent plumose seta with two naked elements at its base (Fig. 8J). Filter comb with seven setae (a-g in Fig. 8J).

Fourth limb (Fig. 8K-M). Pre-epipodite and epipodite not observed. Exopodite quadrangular with six marginal plumose setae; first and third exopodite setae similar in size (third just longer), second, fourth and fifth setae shorter than third and all of similar size (third seta about 1.6 times longer as second seta) (Fig. 8K). Sixth seta markedly short, about a fourth of the fifth seta (Fig. 8K), all are plumose but fourth to sixth setae with shorter setules. Endite (Fig. 
$8 \mathrm{~L}$ and $8 \mathrm{M}$ ) with marginal row of three setae (1'-3' in Fig. $8 \mathrm{M})$, the first a short thick seta (1'), second and third shorter, third almost reduced (3' in Fig. 8M), gradually decreasing in size towards the gnathobase. The first seta (1' in Fig. 8M) with very short setules in distal half (unilaterally armed). One elongate marginal naked sensillum (s in Fig. 8M); gnathobase with one longer seta, bent over flaming torch setae and implanted with setules on the outer margin, and one short projection (Fig. 8L and 8M, gn); on the inner side of the endite, three plumose setae (1"-3" in Fig. $8 \mathrm{~L}$ ) increasing in size towards the filter comb, the latter with five slender setae (Fig. 8L).

Fifth limb (Fig. 8N). Pre-epipodite short and angular, armed with long setules; epipodite rather straight and long, without projectiong. Exopodite oval, about 1.5 times as long as wide, with concave setulated margin between third and fourth exopodite setae; three first exopodite setae plumose and gradually decreasing in size, first (dorsal) longest, longer than the exopodite width; fourth seta relatively long, nearly as long as the third seta; inner portion of limb with wide inner lobe with long apical setules; two endite setae (1'-2' in Fig. $8 \mathrm{~N}$ ) of which first not longer than inner lobe and the second endite seta (2') about half as long, both with thick basis. No gnathobase elements found, except for one round setulated hillock.

Sixth limb. Absent.

Ephippial female, ephippium and male: Unknown.

Differential diagnosis: Karualona serrulata n.sp.

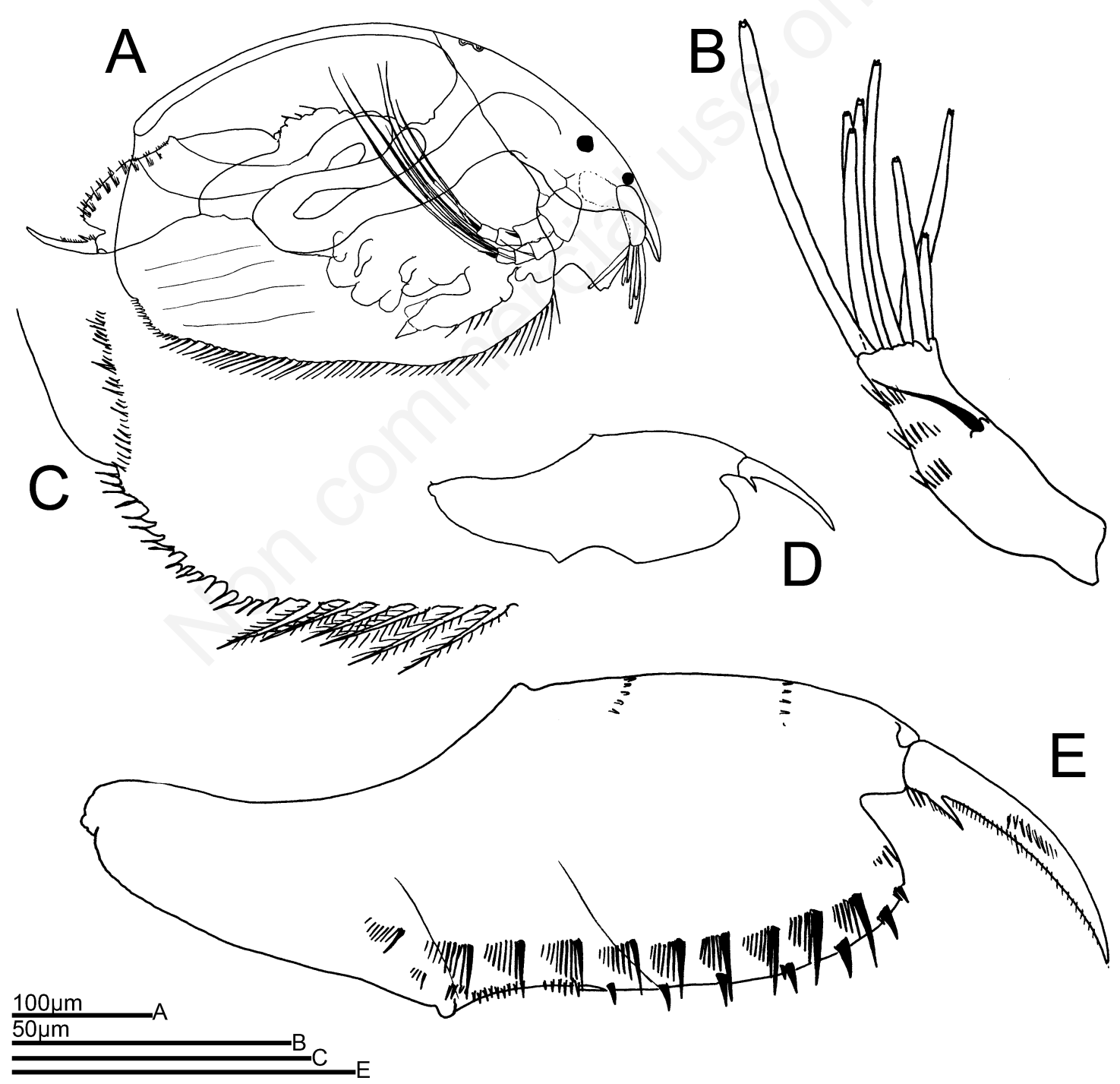

Fig. 5. Karualona serrulata n.sp., adult parthenogenetic females from Natam swamp, collected in April 2000 by K. Van Damme, S. Maiphae and P. Sa-ardrit. A) Habitus, lateral view; B) first antenna; C) posteroventral valve corner; D) postabdomen, countours; E) postabdomen, complete. 
stands out in the genus by the serrulation (instead of two to four large teeth) in the posteroventral corner of the valves. The postabdomen differs from other Karualona species of the Old World in having conical, large marginal teeth in the postanal portion, which are mostly singular, or with one smaller denticle, never groups of denticles. The basal spine on the terminal claw in $K$. serrulata n.sp. is thick and well-developed, much thicker than in other Karualona in SE Asia. Carapace ornamentation faint and always lacking the hexagons (cross-connected large striae) that are typical and common in all other Karualona species. On first limb, single setules on the anterior face, instead of groups, is a unique feature within the genus and a very rare character in the Chydoridae.

Distribution and biology: Karualona serrulata n.sp. has a relatively wide occurrence in S Thailand. Specimens were studied here from three sites: Natam swamp (Trang province), a small swamp at Ratchaprapa dam (Surrathani province) and Kangkao peat swamp (Songkhla province). The sites were very similar at the time of collection: freshwater, shallow, with high coverage of macrophytes (Salvinia) and humic-brown water. All become more acid during the dry season ( $\mathrm{pH} 5-6$ ). During the time of collection, water at the sampling site of Kangkao peat swamp had a temperature of $22.5^{\circ} \mathrm{C}$ (July 2012), dissolved oxygen measured $1.8 \mathrm{mg} \mathrm{O}_{2} \mathrm{~L}^{-1}, \mathrm{pH} 6.75$; the swamp at Ratchaprapa dam was similar, with a $\mathrm{pH}$ of 6.55 (April 2010). Notoalona pseudomacronyx $\mathrm{n}$.sp. has also been found in the same sample of one of these sites (Natam swamp; April 2000). In Trang province, Sa-ardrit (2002) recorded this species as Karualona sp. from several localities, ranging in $\mathrm{pH}$ between 6.15-8.9 (Noblung swamp August 1999, February and August 2000, pH 6.83-8.9; Thale-songhong swamp, August, November 1999 and February, May and August 2000, pH 6.93-8.09; Khaowiset peat swamp, August 1999, $\mathrm{pH}$ 7.95-8.65; Wangbo pond, May 2000, pH 7.16-8.17; Natam swamp, November 1999, February, May, August 2000, pH 6.15-7.7) Recent surveys suggest that the distribution of $K$. serrulata n.sp. extends to Vietnam (Sinev and Korovchinsky, 2013). The species has been found in S Thailand almost exclusively in swamps, despite extensive surveys (Sa-ardrit, 2002; this study).

\section{Karualona cf. karua (King, 1853)}

A few drawings of the common Karualona in S Thailand are shown in Figs. 9-10. Fig. 9 shows the Karualona cf. karua population that is found sympatrically with $K$. serrulata $n$.sp. (same locality, same date, same sample). Some notes on the morphology of the adult parthenogenetic females from Rathchaprapa dam are below. Fig. 10 shows specimens from different localities and is shortly discussed after notes on specimens in Fig. 9.

Material: ten adult parthenogenetic females from a swamp at Ratchaprapa dam, Suratthani province, eastern coast of S Thailand; $08^{\circ} 58.074^{\prime} \mathrm{N}, 098^{\circ} 49.056^{\prime} \mathrm{E}$; collected by S. Maiphae and S. Fangcholjit, 19.IV.2010. Samples kept at PSU, Thailand.

Habitus (Fig. 9A and 9B) 0.32 to $0.35 \mathrm{~mm}$, average $0.33 \mathrm{~mm}$. Body about 1.5 times as long as high with convex curved dorsum with highest point near middle (Fig. 9A) or just behind the head (Fig. 9B). Ventral margin of the valves with deepest point near the middle (Fig. 9B). The posterior margin of the valves is straight to convex in lateral view, the posteroventral corner round with several (two to five, mostly three) strong denticles (Fig. 9D). Dorsal keel absent. Head. Ocellus smaller than eye (diameter of eye about 1.3 times the diameter of the ocellus), equidistant between latter and rostrum (Fig. 9B). Rostrum not strongly protruding, rather wide and blunt (Fig. 9F). Antennular corms not reaching apex of rostrum, aesthetascs projecting beyond it. Headshield about 1.35 times as long as broad, with two main connected headpores and two lateral small pores (Fig. 9E and 9F). Main headpores situated about 3.5 interpore distance (distance between the two main pores) from posterior margin of headshield (Fig. 9E), postpore distance $(\mathrm{PP})=3.5$ interpore distance (IP) in this population (but can vary strongly, $\mathrm{PP}=2.5-3.5 \mathrm{IP})$, lateral pores are about 1.9-2 times the interpore distance from the midline and very small. Carapace. Transparent. Ornamentation strong longitudinal striation of wide striae in the frontal portion (Fig. 9A and 9B) and strong hexagonal patterns in the posterior and median portions (Fig. 9G). Marginal setae around 50, differentiated into three groups, each covering about a third of the ventral carapace margin except for the first group (of long setae), which ends a bit earlier. All the marginal setae are implanted marginally on the valve. The posteroventral corner as described above, without strong embayment. Antennules (Fig. 9C). Relatively short, about 2.5 times as long as wide, with sensory seta implanted between half and about one third from the apex, on a small projection (Fig. 9C). At least three rows of denticles, not setules, on the antennular corm (Fig. 9C). Postabdomen (Fig. 9M and 9N). Deepest at the postanal corner. Dorso-distal embayment present near the basis of the terminal claw (Fig. 9M), the dorso-distal angle projecting. Postanal margin rather straight and tapering distally (Fig. 9M). Length about two to 2.3 times as long as wide. Ventral margin straight, shorter than anal and postanal margins together. Postanal margin longer than anal margin (about 2 times as long) (Fig. 9L). Anal margin concave to straight, preanal corner weak (Fig. 9M) to small angular (Fig. 9L), postanal margin relatively straight, distal margin protruding. Postanal angle distinct (Fig. 9M). Six to seven postanal marginal denticle groups of one-two distally and three-five near anal margin (Fig. $9 \mathrm{M})$. These denticles relatively small and conical. Lateral fascicles seven to eight groups in postanal portion, the distalmost groups with about seven spinules per group, paral- 


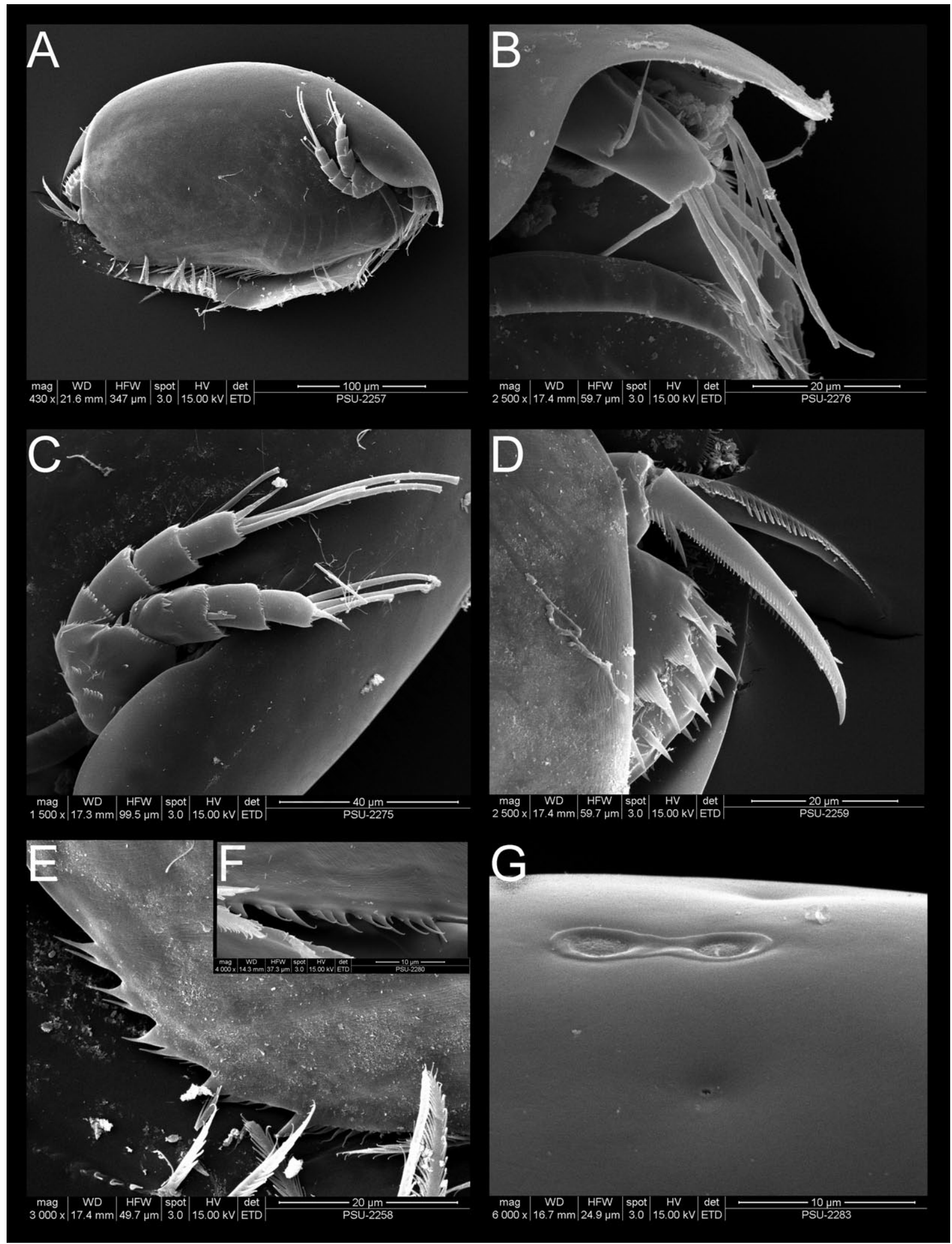

Fig. 6. Karualona serrulata n.sp., scanning electron microscopy of adult parthenogenetic females from a swamp at Ratchaprapa dam, Suratthani province, Southern Thailand, collected in April 2010 by S. Maiphae and S. Fangcholjit. A) Habitus, lateral view; B) rostrum and first antenna, lateral view; C) second antenna, lateral view; D) postabomen, distal portion and terminal claw; E,F) posteroventral valve corner; G) head pores, lateral view. 
lel to each other, distalmost spinule strongly developed (Fig. 9M). Longest, distal spines in lateral fascicles reach clearly beyond the marginal denticles (Fig. 9M). The lateral fascicles and marginal denticles continue on the anal margin, the lateral fascicles forming one row of about four to five groups (Fig. 9M), marginal denticles in about three groups of each six to seven or more teeth. Terminal claw (Fig. 9M and 9N). About 1.8 times as long as anal margin, rather curved. Proximal and distal dorsal pecten well developed, length of spinules reaching beyond the length of the basal spine (Fig. 9N). Basal spine nearly absent (Fig. $9 \mathrm{~N}$ ), about one third to one fourth of the claw width at base and not much longer than the basal spinules (Fig. 9N). Five limbs, first limb with three IDL setae (Fig. 9I) of which the smallest is just less than half the size of the other two and the armature of the thickest IDL seta consists of strong se-

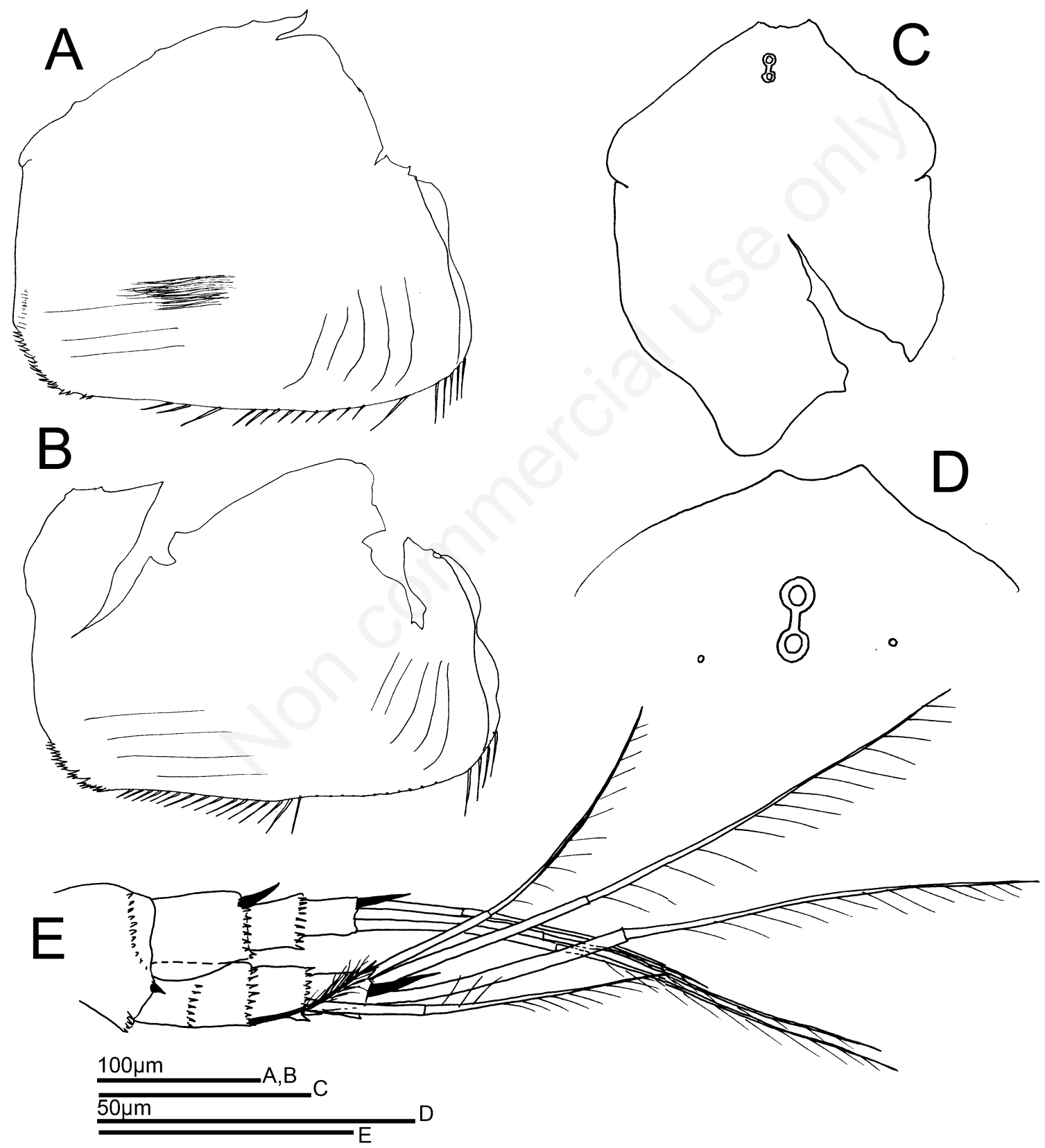

Fig. 7. Karualona serrulata n.sp., adult parthenogenetic females from a swamp at Ratchaprapa dam, Suratthani province, Southern Thailand, collected in April 2010 by S. Maiphae and S. Fangcholjit. A,B) Carapace (or valve); C) headshield; D) headpores and posterior margin of headshield; E) second antenna. 


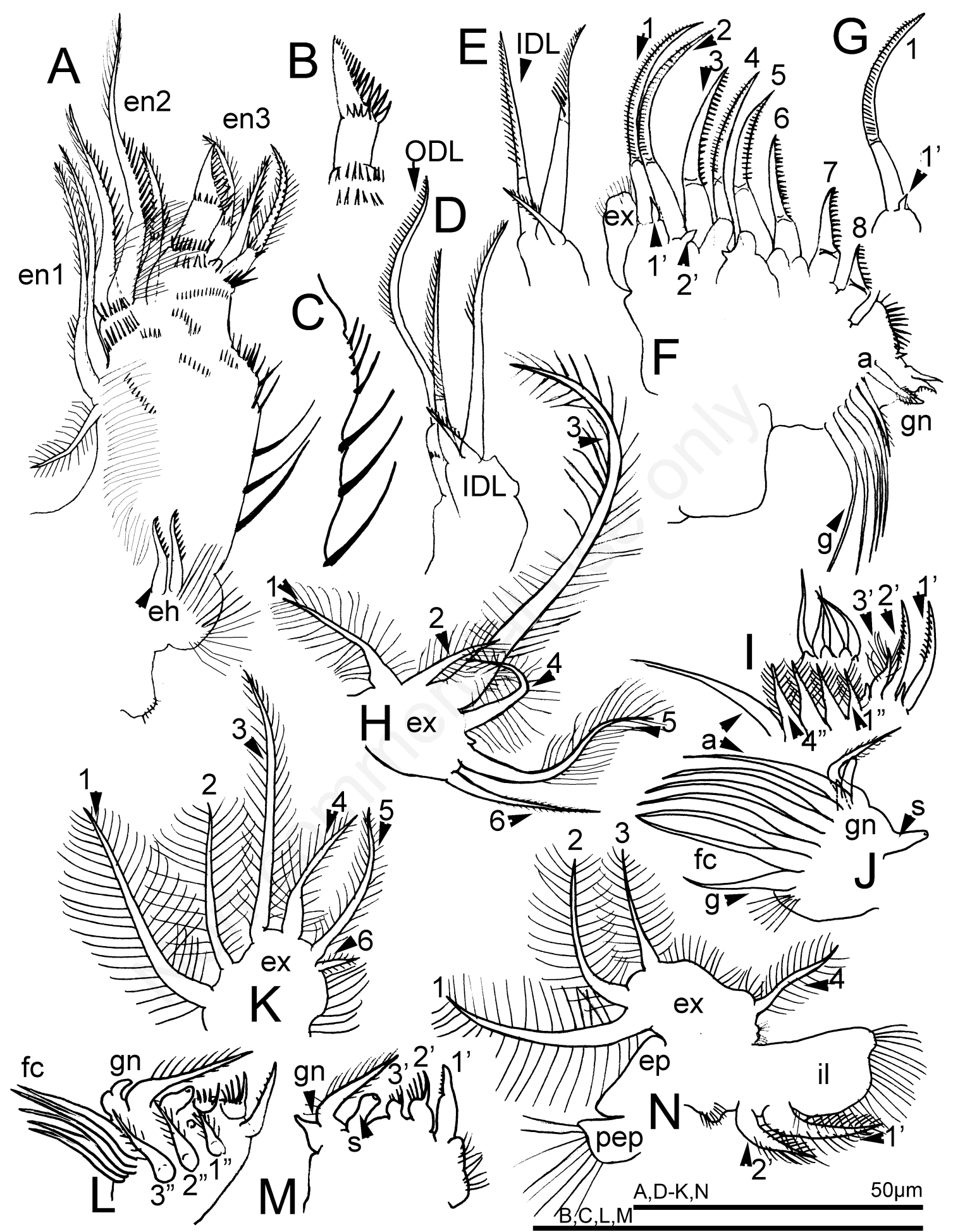

Fig. 8. Karualona serrulata n.sp., adult parthenogenetic females from a swamp at Ratchaprapa dam, Suratthani province, Southern Thailand, collected in April 2010 by S. Maiphae and S. Fangcholjit. A) First limb; B) first limb, modified conical seta on third endite; C) first limb, anterior setules; D,E) first limb; F) second limb, scrapers numbered 1-8 and anterior elements 1'-2'; G) second limb, first scraper (1) with anterior basal element (1'); H) third limb, exopodite (exopodite setae numbered 1-6); I) third limb, endite (endite setae numbered 1'-3' and 1"-4"); J) third limb, endite (gnathobase and filter comb; filter comb setae numbered a-g); K) fourth limb, exopodite (exopodite setae numbered 1-6); L,M) fourth limb, endite (flaming torch setae 1'-3'; inner endite setae 1"-3"); N) fifth limb (exopodite setae 1-4; inner setae 1'-2'). en=endite; IDL=inner distal lobe; ODL=outer distal lobe; ex=exopodite; a-g=numbering of setae in gnII; $\mathrm{gn}=$ gnathobase; $\mathrm{fc}=$ filter $\mathrm{comb} ; \mathrm{s}=$ sensillum; $\mathrm{pep}=$ pre-epipodite; $\mathrm{ep}=$ =pipodite; $\mathrm{il}=$ inner lobe. 


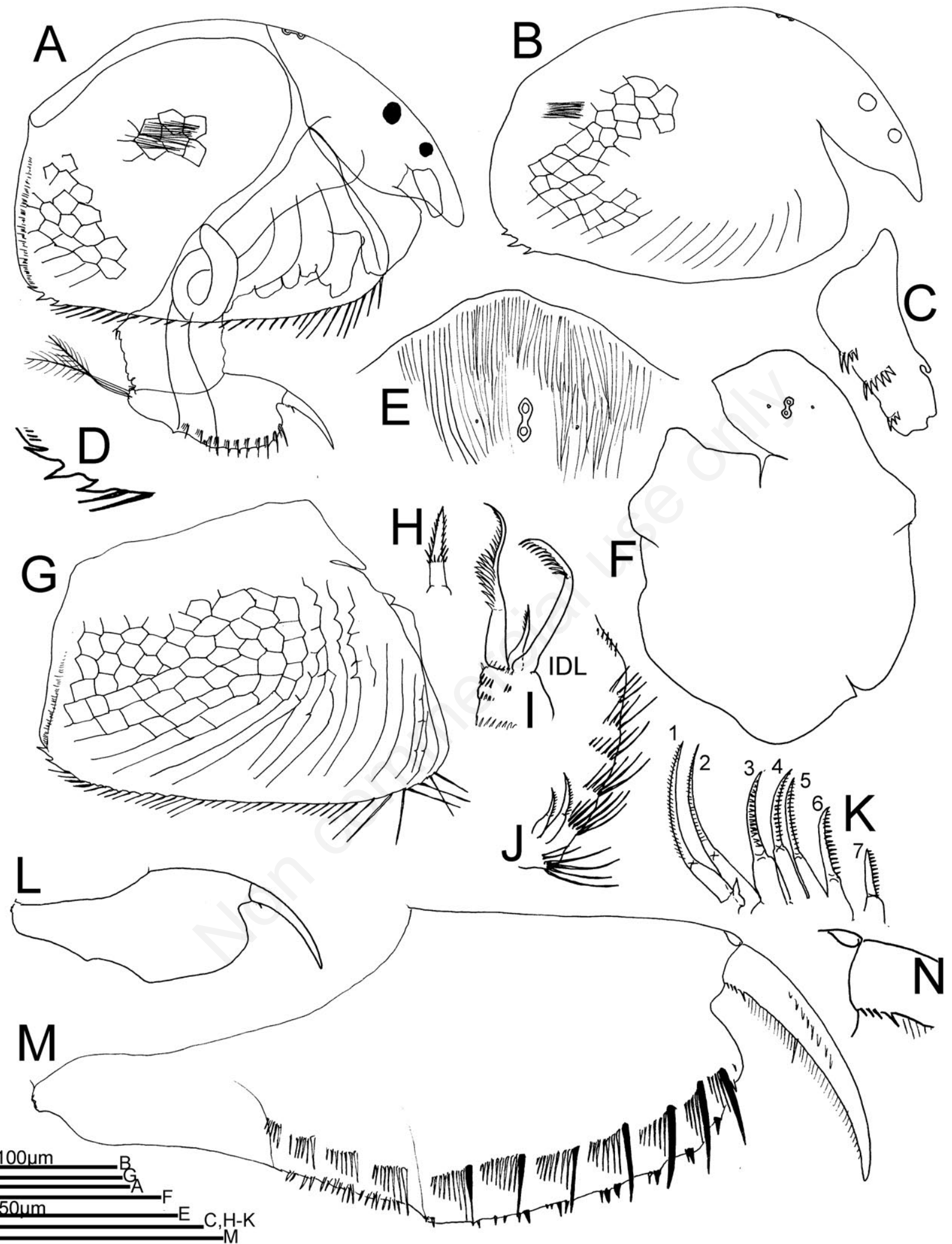

Fig. 9. Karualona cf. karua, adult parthenogenetic females from a swamp at Ratchaprapa dam, Suratthani province, Southern Thailand, collected in April 2010 by S. Maiphae and S. Fangcholjit. A,B) Habitus, lateral view; C) first antenna, setae and aesthetascs omitted; D) posteroventral valve corner; E) posterior margin of headshield and headpores; F) headshield; G) carapace; H) first limb, conical seta on third endite (compare with Fig. 8B); I) first limb; J) first limb, anterior setule groups; K) second limb, scrapers one to eight (1-7; eight is not shown); L) postabdomen, contours; M) postabdomen; N) postabdomen, (minute) basal spine on terminal claw. IDL=inner distal lobe. 
tules in distal half, the second has shorter setules. Thickest seta on third endite (Fig. 9H) with conical setules forming a crown around the middle, but seta not as thick as in $K$. serrulata. Anterior setules on first limb in about six to seven groups (Fig. 9J), decreasing in size ventrally (Fig. 9J). Second limb (Fig. 9K) with eight scrapers on the endite, decreasing in size towards gnathobase (only seven shown in Fig. 9K but there are eight). First two scrapers slender, finely setulated and of similar length, third scraper markedly shorter than second but of same size of fifth, while fourth is just longer than scraper 3 and 5, sixth markedly shorter and seventh about half the sixth (Fig. 9K).

Notes: This is the most common form in S Thailand, but variability is high, sometimes ranging between $K$. karua and $K$. iberica. In comparison to true Australian $K$. karua after Alonso and Pretus (1989) and Dumont and Silva-Briano (2000), the Thai populations differ in several characters, for example in the headpores - IP/PP distance, in K. karua $\mathrm{PP}=2 \mathrm{IP}$ (Alonso and Pretus, 1989), in Thai populations this is more ( $\mathrm{PP}=2.5-3.5 \mathrm{IP})$, as in K. iberica, while on the other hand the dimensions of the postabdomen generally are closer to K. karua (although forms in between exist; see next point). The headshield is also rounded in its posterior-distal margin, forming a rounded distal angle, yet in K. karua this posterior margin of the head shield is straight and perpendicular to the midline [for latter see Alonso and Pretus (1989)]. Another difference is the presence of rows of denticles on the first antenna in the Thai population, but stability of this character should be confirmed. Limb characters, which normally help in understanding true relationships, are not as informative here.

\section{Variability of traits in Thai Karualona sp. (cf. karua) populations}

Fig. 10 shows the postabdomen, posteroventral valve corner and the second limb of three populations of Karualona sp. in S Thailand. For this brief section on the variability of characters, the three populations, each from a locality in a different province (e.g. Thale Noi wetland) (Fig. 10) are discussed jointly with the population from the swamp at Ratchaprapa dam (Fig. 9).

It is clear from the drawings of the three structures that are important in the species diagnosis of the genus (Figs. 9 and 10), that there are strong differences in the size of the basal spine (from minute absent to long, yet always fine; Figs. 9M and 10A vs 10D), in the length of the proximal pecten (short to long; Fig. 9M vs 10A), differences in the postabdomen shape and the depth of the embayment near the basal claw (Fig. 10A vs 10G; yet always anal margin shorter than postanal margin; embayment present but sometimes very shallow, Fig. 10D), in the orientation and number and shape of the posteroventral valve teeth (Fig. 10B vs 10E-H; two to five; oriented posteriorly or more curved) and in the lengths of scrapers of the second limb (scrapers 1-2 and 3-5) (Fig. 10C, 10F and 10I). In some populations, the first two scrapers on limb 2 are nearly the same size as the third to fifth scraper (Fig. 10C), in others they are both longer yet vary in relative length compared to third to fifth scrapers (Fig. 10F and 10I); the fourth scraper can sometimes be longer (Figs. 9K and 10I) or the same size as scrapers three and five (Fig. 10C and 10F). In all cases, the first two scrapers are of the same length in these populations.

A wider examination of the morphology of Karualona sp. populations ( 465 specimens from 55 sampling sites in S Thailand; Maiphae and Pholpunthin, 2009), confirms the variability. These populations do not include $K$. serrulata n.sp., only the Thai Karualona sp. (cf. karua) populations (Figs. 9 and 10). Limbs are depicted in Maiphae et al. (2005). From this wide survey, the characters that show high variation (Fig. 10), are: i) size, number and orientation of the posteroventral denticles on the valves, which range from wide to narrow, long to short, and from oriented posterodorsal to more posterior. Number of posteroventral denticles on the valves range from one to five; ii) length of scrapers on the second limb. In particular, the scrapers one to three, vary strongly in length. Scraper two can be longer than (or of same length as) the first scraper, and it can be shorter than, or have the same length as, scraper three. According to these structures, used in the key by Dumont and Silva-Briano (2000), several specimens showed overlap between iberica and karua; iii) embayment at the basis of the terminal claw. The embayment is present in the Thai populations, yet has a wide range of depths, from deep to shallow.

In fact, characters that showed lower variation between these populations, are: i) shape of the labral keel (ear-shaped); ii) relative length of ODL seta $v s$ IDL seta on limb 1 (1.2-1.3 times); iii) relative length of third vs fourth (1.5 times), and fourth $v$ fifth exopodite setae on limb 3 (same length); iv) relative length of fourth $v s$ fifth exopodite setae on limb 5 (same length); v) PP $v s$ IP distance on the headshield (2.5-3.5 times); vi) shape of preanal angle (round/blunt) and height of postanal angle (low); vii) setules of the proximal comb on terminal claw of postabdomen (PA) (mostly short); viii) width at postanal and preanal corners of postabdomen; ix) number of lateral fascicles groups on postabdomen (7-11 groups); $\mathrm{x})$ pattern of marginal denticles on the postabdomen (but ranging from single denticles to groups); xi) relative length (as opposed to width) of postabdomen (2.5 times longer than wide).

\section{Cladoceran species in swamps and peat swamps}

We counted a total of 73 cladoceran taxa from 22 inland swamp localities (ten provinces) in S Thailand (including Phuket island), sampled between 1999-2012 
(Tabs. 1 and 2), most in the period of 1999-2002 (Tab. 2). The total number of cladoceran taxa in Thailand is 99 according to Maiphae et al. (2008), yet the current tally for the country amounts to ca. 110 taxa now (including new species and new records found since), of which approximately 86 taxa have been recorded from $\mathrm{S}$ Thailand (S. Maiphae, unpublished data). This means that the total number of cladoceran taxa found in swamps, makes up roughly about $85 \%$ of the cladoceran taxa found in $\mathrm{S}$
Thailand, and ca. $68 \%$ of the total number of taxa found in the country. The localities in Tab. 1 include a wide range of swamp habitats, from alluvial swamps to brackish peat swamps. The location of the sampling sites is shown in Fig. 11. A revision of the records in Sa-ardrit (2002), on the Cladocera of swamps in Trang province (S Thailand), revealed that Yon peat swamp and Natam swamp were the richest in species (43 and 41 species respectively). The species from the latter two localities can

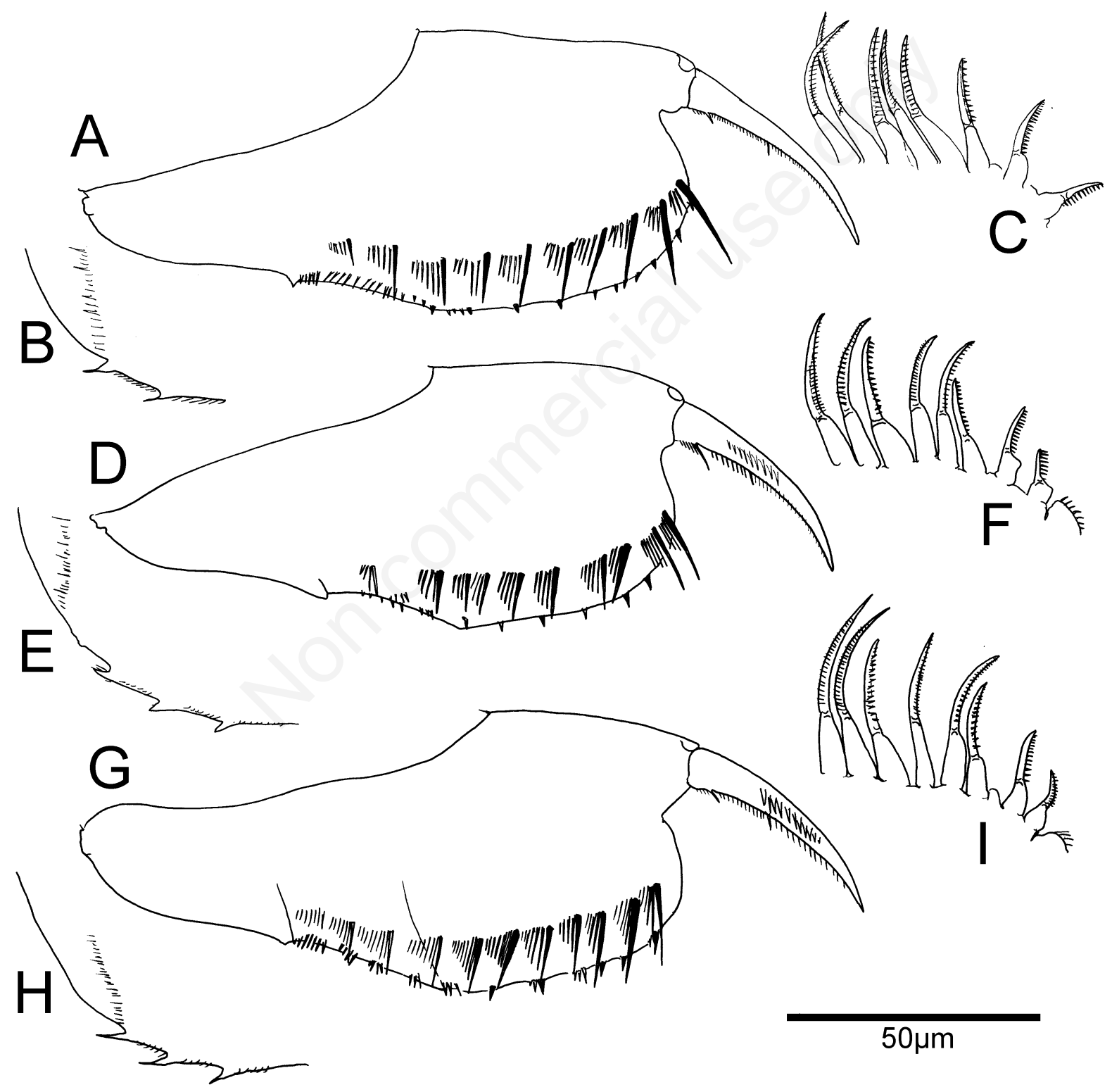

Fig. 10. Karualona sp., adult parthenogenetic females from Southern Thailand. Comparison of postabdomen (A,D,G), posteroventral valve corner (B,E,H) and second limb (C,F,I). A-C) K. cf. karua (iberica form) from Thale Noi wetland, Pattalung province, collected in January 2006 by S. Maiphae; D-F) K. cf. karua from Kla swamp, Chumphon province, collected in April 2000 by S. Maiphae; G-I) K. sp. (cf. karua) from Rattaphum district, Ricefield, collected in November 2008 by S. Maiphae. 
Tab. 1. Cladocera found in swamps and peat swamps in South Thailand. Localities are shown in Fig. 11, sampling dates in Tab. 2. We refer also to Maiphae et al. (2008), Korovchinsky (2013), Sinev and Korovchinsky (2013) and Kotov et al. (2013) for additional comments on the species listed below.

\begin{tabular}{lll}
\hline Number & Species list $^{*}$ & Note \\
\hline i & Family Bosminidae & \\
ii & Bosminopsis deitersi Richard, 1895: 4, 9, 10, 11, 12, 15, 19,21, 22 & Circumtropical species (or unrevised group) (Kotov et al., 2013) \\
\cline { 2 - 3 } & $\begin{array}{l}\text { Bosmina (Liederobosmina) meridionalis Sars, 1904: 10, 11,12, } \\
15,20\end{array}$ & $\begin{array}{l}\text { Also Sinobosmina fatalis Burckhardt, 1924 is known from the region } \\
\text { (Maiphae } \text { et al., 2008) but it has not been found in swamps. Taxonomy } \\
\text { of Bosmina in SE Asia should be revised }\end{array}$ \\
\hline
\end{tabular}

\begin{tabular}{|c|c|c|}
\hline & Family Chydoridae & \\
\hline iii & Acroperus harpae (Baird, 1834): 2, 4, 19 & $\begin{array}{l}\text { Palaearctic species but widespread species group (Sinev, 2009). SE Asian } \\
\text { populations unrevised }\end{array}$ \\
\hline iv & Alona sp.: 11 & Unknown \\
\hline $\mathrm{v}$ & Alona cf. affinis Leydig, 1860: 9, 10, 11, 12, 15, 19, 20 & $\begin{array}{l}\text { Palaearctic species but widespread species group. Identity of SE Asian } \\
\text { populations is unclear, this should be checked against the Australian } \\
\text { Alona kendallensis and Alona elliptica. See Van Damme et al. (2010) } \\
\text { for comments }\end{array}$ \\
\hline vi & Alona archeri Sars, 1888: 19, 20, 21 & $\begin{array}{l}\text { Confused with earlier records of Alona cf. karelica in SE Asia, see } \\
\text { Maiphae et al. (2008) }\end{array}$ \\
\hline vii & Alona cf. cambouei de Guerne \& Richard, 1893: 3, 15, 22 & $\begin{array}{l}\text { Populations from locality } 22 \text { are depicted in Maiphae et al. (2008), clearly } \\
\text { showing the separate headpores of } A \text {. cambouei. In SE Asia, records of } \\
\text { both } A \text {. cambouei and } A \text {. pulchella occur, but the latter should be checked }\end{array}$ \\
\hline viii & Alona cheni Sinev, 1999: 7, 15, 22 & $\begin{array}{l}\text { Species of the } A \text {. costata group, identification shown in Maiphae et al. } \\
\text { (2008) }\end{array}$ \\
\hline ix & Alona costata Sars, $1862: 9,10,11,15$ & $\begin{array}{l}\text { Could be Palaearctic } A \text {. costata, or a second species of the same group in } \\
\text { SE Asia besides } A \text {. cheni }\end{array}$ \\
\hline $\mathrm{x}$ & Alona guttata Sars, $1862: 8,9,10,11,12,13,15$ & $\begin{array}{l}\text { Palaearctic species, yet globally unrevised species group, SE Asian } \\
\text { populations unrevised (Van Damme et al., 2010). It is unclear whether } \\
\text { A. guttata actually has a very wide distribution or not }\end{array}$ \\
\hline xi & Alona cf. intermedia Sars, 1862: 9, 10 & Globally unrevised species group (Van Damme et al., 2010) \\
\hline xii & Alona cf. quadrangularis (O.F. Müller, 1776): 11 & $\begin{array}{l}\text { Palaearctic species, this record is most likely A. kotovi Sinev, 2012, } \\
\text { recently described from Vietnam (Sinev and Kotov, 2012), but the identity } \\
\text { has not been confirmed yet }\end{array}$ \\
\hline xiii & Alona sarasinorum Stingelin, 1900: 16 & $\begin{array}{l}\text { Halophile species, only occurs in brackish environments (Van Damme } \\
\text { and Maiphae, 2013) }\end{array}$ \\
\hline xiv-xv & $\begin{array}{l}\text { Anthalona sp.: 1, 3, 4, 7, 8, 9, 10, 11, 12, 13, 14, 16, 17, 18, 19, 20, } \\
21,22\end{array}$ & $\begin{array}{l}\text { This record comprises two species, Anthalona harti Van Damme, Sinev } \\
\text { \& Dumont, } 2011 \text { and Anthalona sanoamuangae Sinev \& Kotov, } 2012 \\
\text { (Van Damme } \text { et al., 2011; Sinev and Kotov, 2012), but the two species } \\
\text { have not been separated here according to locality }\end{array}$ \\
\hline xvi & Alonella cf. excisa (Fischer, 1854): 4, 7, 8, 9, 10, 11, 12, 13, 14 & Palaearctic species but widespread species group (Smirnov, 1996) \\
\hline xvii & Alonella (Nanalonella) cf. nana (Baird, 1843): 7, 8, 9, 11, 22 & Palaearctic species but widespread species group \\
\hline xviii & Camptocercus australis Sars, 1896: 11 & \\
\hline xix & Celsinotum macronyx (Daday, 1898): 12, 18 & Former Alona macronyx, moved to Celsinotum by Sinev and Kotov (2012) \\
\hline $\mathrm{xx}$ & $\begin{array}{l}\text { Chydorus cf. eurynotus Sars, } 1901: 4,6,7,10,11,12,13,15,16 \text {, } \\
17,18,19,20,21,22\end{array}$ & $\begin{array}{l}\text { Neotropical species, SE Asian populations remain to be distinguished. } \\
\text { Common in the region (Sinev and Korovchinsky, 2013) }\end{array}$ \\
\hline $\mathrm{xxi}$ & Chydorus obscurirostris Frey, 1987: 10, 11, 12 & \\
\hline xxii & Chydorus opacus Frey, 1987: 11, 12 & \\
\hline xxiii & Chydorus parvus Daday, 1898: 9, 10, 11, 12, 18, 19 & Relatively common species \\
\hline xxiv & Chydorus cf. pubescens Sars, 1901: 10, 11, 12 & $\begin{array}{l}\text { Neotropical species, SE Asian populations remain to be revised. Common } \\
\text { in the region (Sinev and Korovchinsky, 2013) }\end{array}$ \\
\hline $\mathrm{xxV}$ & Chydorus reticulatus Daday, 1898: 10, 11, 12 & \\
\hline
\end{tabular}


Tab. 1. Continued from previous page.

\begin{tabular}{|c|c|c|}
\hline Number & Species list & Note \\
\hline xxvi & Chydorus ventricosus Daday, 1898: 10, 11, 14, 16, 17 & $\begin{array}{l}\text { Very common in the region, found in a wide range of habitats. It occurs } \\
\text { throughout the tropics (Van Damme and Dumont, 2010) but records } \\
\text { outside of the Oriental zone should be revised }\end{array}$ \\
\hline xxvii & Coronatella cf. monacantha (Sars, 1901): 4, 10, 11, 12, 16, 21 & $\begin{array}{l}\text { Former Alona cf. monacantha. Likely Coronatella acuticostata (Sars, } \\
\text { 1903), which needs revision. True Coronatella monacantha is limited to } \\
\text { the Neotropics. See notes in Van Damme et al. (2010) }\end{array}$ \\
\hline xxviii & Coronatella cf. rectangula (Sars, 1862): 9, 15, 16 & $\begin{array}{l}\text { Former Alona rectangula. Many species of this group remain to be defined } \\
\text { in the region, C. rectangula is Palaearctic, and even there it is very } \\
\text { confusing (Van Damme et al., 2010) }\end{array}$ \\
\hline xxix & Dadaya macrops (Daday, 1898): 2, 10, 11, 12, 21 & $\begin{array}{l}\text { Relatively common species, considered circumtropical (but also needs } \\
\text { revision) (Smirnov, 1996) }\end{array}$ \\
\hline $\mathrm{xxx}$ & Dunhevedia crassa King, 1853: 1, 20, 22 & Common species in the tropics, but likely a complex (Smirnov, 1996) \\
\hline xxxi & Dunhevedia serrata Daday, 1898: 3, 10, 11, 12, 16, 21 & \\
\hline xxxii & Ephemeroporus sp.: 10 & Unclear species; could be new (Maiphae, unpublished data) \\
\hline xxxiii & $\begin{array}{l}\text { Ephemeroporus barroisi (Richard, 1894): 1, 2, 4, 7, 8, 9, 10, 11, } \\
\text { 12,13,14, 16, 17, 18, 19, 20, } 21\end{array}$ & Widespread circumtropical occurrence \\
\hline xxxiv & Ephemeroporus cf. phintonicus (Margaritora, 1969): 1, 16, 17, 22 & Palaearctic species, SE Asian populations unclear \\
\hline $\operatorname{xxxv}$ & Ephemeroporus tridentatus (Bergamin, 1939): 1, 16, 17, 22 & \\
\hline xxxvi & Euryalona orientalis (Daday, 1898): 2, 6, 11, 12, 15 & $\begin{array}{l}\text { Typical for macrophyte-rich environments, redescription in Van Damme } \\
\text { and Maiphae (2013) }\end{array}$ \\
\hline xxxvii & Graptoleberis cf. testudinaria Fisher, 1851: 9 & $\begin{array}{l}\text { Palaearctic species but widespread species group, yet not so common in } \\
\text { SE Asia }\end{array}$ \\
\hline xxxviii & Karualona serrulata $\mathrm{n} . \mathrm{sp} .: 6,10,12,15$ & New species (this study) \\
\hline xxxix & $\begin{array}{l}\text { Karualona ef. karua (iberica form): 5, 6, 7, 12, 16,20,21,22; } \\
\text { other: } 15\end{array}$ & $\begin{array}{l}\text { Unclear identity (this study); until we are certain of the identity of these } \\
\text { populations, they should fall under one record, yet these may comprise } \\
\text { more than one species }\end{array}$ \\
\hline $\mathrm{xl}$ & Kurzia longirostris (Daday, 1898): 6, 10, 15, 21, 22 & Very common in the region (Korovchinsky, 2013) \\
\hline xli & Leberis diaphanus (King, 1853): 6, 10, 11, 14, 18, 21, 22 & $\begin{array}{l}\text { Former Alona diaphana King, 1853. More than one species could be } \\
\text { present in SE Asia (Kotov et al., 2013) }\end{array}$ \\
\hline xlii & Leydigia ciliata (Gauthier, 1939): 22 & $\begin{array}{l}\text { Widespread taxon in the tropics, but see notes in Sinev and Sanoamuang } \\
\text { (2011) and Kotov et al. (2013) for SE Asia }\end{array}$ \\
\hline xliii & Leydigiopsis $\mathrm{sp} .: 12$ & $\begin{array}{l}\text { New species, very rare in S Thailand, described in Van Damme and Sinev } \\
\text { (2013) }\end{array}$ \\
\hline xliv & Nicsmirnovius eximius (Kiser, 1948): 2 & Former Alona eximia Kiser, 1948, rheic species \\
\hline xlv & Notoalona globulosa (Daday, 1898): 7,11,12,22 & See this study \\
\hline xlvi & Notoalona cf. freyi Idris \& Fernando, 1987: 7, 22 & $\begin{array}{l}\text { Originally from N America (Florida), SE Asian populations need revision. } \\
\text { This study }\end{array}$ \\
\hline xlvii & Notoalona pseudomacronyx n.sp.: 12 & See this study \\
\hline xlviii & Oxyurella singalensis (Daday, 1898): 6, 9, 10, 11, 12, 15, 18, 22 & $\begin{array}{l}\text { Common species in the region, also in neighbouring countries } \\
\text { (Korovchinsky, 2013; Kotov et al., 2013; Sinev and Korovchinky, 2013) }\end{array}$ \\
\hline xlix & Picripleuroxus cf. laevis (Sars, 1862): 6, 10, 12 & $\begin{array}{l}\text { Palaearctic species but widespread species group, with most likely different } \\
\text { taxa in SE Asia (and names are available in the region from S China). See } \\
\text { also Kotov et al. (2013) (Laos) and Sinev and Korovchinsky (2013) } \\
\text { (Vietnam) }\end{array}$ \\
\hline \multirow[t]{2}{*}{1} & Picripleuroxus quasidenticulatus Smirnov, 1996: 11 & \\
\hline & Family Daphniidae & \\
\hline li & Ceriodaphnia cornuta Sars, 1885: 10, 11, 12, 13, 15, 19, 20, 21, 22 & Common species in the region \\
\hline
\end{tabular}


Tab. 1. Continued from previous page.

\begin{tabular}{|c|c|c|}
\hline Number & Species list & Note \\
\hline lii & Scapholeberis kingi Sars, 1888: 10, 11, 12, 17, 19, 21 & Common species in the region \\
\hline liii & $\begin{array}{l}\text { Simocephalus heilongjiangensis Shi Xinlu \& Shi Xinbai, 1994: 10, } \\
11,12\end{array}$ & $\begin{array}{l}\text { Previously recorded as Simocephalus mesorostris but the latter is a } \\
\text { junior synonym }\end{array}$ \\
\hline \multirow[t]{2}{*}{ liv } & Simocephalus serrulatus (Koch, 1841): 4, 7, 9, 10, 11, 12, 15, 18 & Widespread and complex species group \\
\hline & Family Ilyocryptidae & \\
\hline \multirow[t]{2}{*}{ lv } & $\begin{array}{l}\text { Ilyocryptus cf. spinifer Herrick, 1882: 2, 7, 9, 10, 11, 12, 18, 20, } \\
21,22\end{array}$ & Widespread species \\
\hline & Family Macrothricidae & \\
\hline lvi & Grimaldina cf. brazzai Richard, 1892: 12, 22 & $\begin{array}{l}\text { Described from Democratic Republic of Congo, but unrevised } \\
\text { circumtropical species group, of which SE Asian populations remain } \\
\text { unresolved }\end{array}$ \\
\hline lvii & Guernella cf. raphaelis Richard, 1892: 12, 15, 20, 21, 22 & $\begin{array}{l}\text { Described from Democratic Republic of Congo, but unrevised } \\
\text { circumtropical species group, of which SE Asian populations remain un } \\
\text { resolved }\end{array}$ \\
\hline lviii & $\begin{array}{l}\text { Macrothrix flabelligera Smirnov, 1992: 2, 4, 7, 8, 9, 10, 11, 12, } \\
13,16,17,18,19,22\end{array}$ & Widespread species group \\
\hline lix & Macrothrix malaysiensis Idris \& Fernando, 1981: 22 & Oriental species; see notes in Kotov et al. (2005) \\
\hline \multirow[t]{2}{*}{ lx } & Macrothrix odiosa Gurney, 1916: 7, 9, 10, 11, 18, 22 & \\
\hline & $\begin{array}{l}\text { Macrothrix pholpunthini Kotov, Maiphae \& Sanoamuang, 2005: } \\
\text { 11, } 12\end{array}$ & Species of the M. paulensis group (Kotov et al., 2005) \\
\hline 1xi & $\begin{array}{l}\text { Macrothrix spinosa King, } 1853: 4,8,10,11,12,13,15,16,20 \text {, } \\
21,22\end{array}$ & \\
\hline lxii & Macrothrix triserialis Brady, 1886: 1, 2, 6, 20, 21, 22 & Widespread circumtropical species group \\
\hline 1xiii & Sreblocerus cf. pygmaeus Sars, 1901: 4, 9, 10, 11, 17 & $\begin{array}{l}\text { Neotropical species, SE Asian populations remain to be distinguished. See } \\
\text { also Van Damme and Sinev (2013) }\end{array}$ \\
\hline
\end{tabular}

Family Moinidae

lxiv $\quad$ Moina micrura micrura Kurz, 1875: 10, 12, 15, 20, 21, 22

lxv Moinodaphnia macleayi (King, 1853): 2, 9, 10, 11, 12, 15, 16, 17, 21,22

\begin{tabular}{|c|c|c|}
\hline & Family Sididae & \\
\hline lxvi & $\begin{array}{l}\text { Diaphanosoma excisum Sars, } 1885: 5,6,8,10,11,12,15,17,19,20 \text {, } \\
21,22\end{array}$ & \\
\hline 1xvii & Diaphanosoma voltzi Stingelin, 1905: 10,12 & \\
\hline 1xviii & $\begin{array}{l}\text { Latonopsis australis Sars, 1888: 1, 7, 8, 9, 10, 11, 12, 15, 16, 18, } 19 \text {, } \\
20,22\end{array}$ & \\
\hline lxix & Pseudosida cf. bidentata Herrick, 1884: 5, 9, 11, 12, 15, 16, 21, 22 & Neotropical species, SE Asian populations remain unclear \\
\hline $1 \mathrm{xx}$ & Pseudosida cf. ramosa (Daday, 1904): 19 & Neotropical species, SE Asian populations unclear status \\
\hline $1 \mathrm{xxi}$ & Sarsilatona papuana (Daday, 1900): 22 & New record for Thailand (note: taxonomy needs to be checked) \\
\hline lxxii & Sarsilatona cf. serricauda (Sars, 1901): 12 & Neotropical species, SE Asian populations remain unclear \\
\hline 1xxiii & Sida crystallina (O.F. Müller, 1776): 17 & Widespread tropical species group \\
\hline
\end{tabular}

"Numbers listed beside each species refer to localities where Cladocera were found.

1, Nongkla (Chumporn province); 2, Lum (Suratthani province); 3, Len (Suratthani province); 4, Kangkao (Suratthani province); 5, Thung-nongkwai (Suratthani province); 6, swamp at Ratchaprapa dam (Suratthani province); 7, Taew (Krabi province); 8, Jude (Trang province); 9, Lampeng (Trang province); 10, Khaowiset (Trang province); 11, Yon (Trang province); 12, Natam (Trang province); 13, Teang (Satun province); 14, Prayod (Songkla province); 15, Kangkao (Songkla province); 16, Kaekae (Pattani province); 17, Lankwai (Pattani province); 18, Kabae (Yala province); 19, Judedang (Narathiwas province); 20, Jae-son (Phuket province); 21, Jik (Phuket province) 22, Maikhao (Phuket province). SE, South East; S, South; N, North 


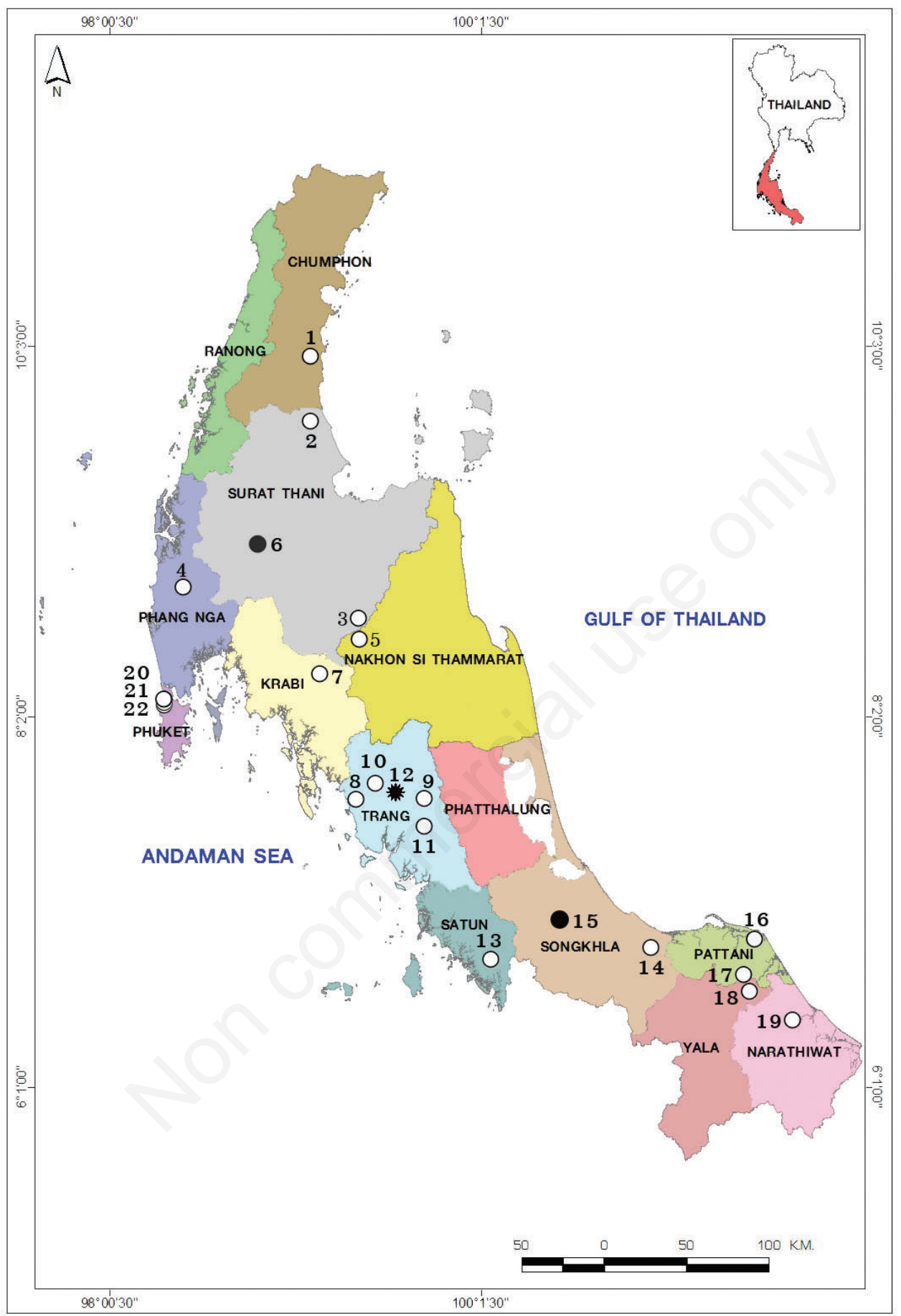

Fig. 11. Map of Southern Thailand showing the swamp sites examined (1999-2012). The Cladocera from these sites are listed in Tab. 1, while sampling dates in Tab. 2. Empty circles indicate all sites of the survey, full circles are the sites where Karualona serrulata n.sp. specimens were taken from during this study, while the full star is Natam swamp, Trang province, which harbours both Karualona serrulata $\mathrm{n}$. sp. and Notoalona pseudomacronyx n.sp. 1, Nongkla (Chumporn province); 2, Lum (Suratthani province); 3, Len (Suratthani province); 4, Kangkao (Suratthani province); 5, Thung-nongkwai (Suratthani province); 6, swamp at Ratchaprapa dam (Suratthani province), type locality of $K$. serrulata n.sp.; 7, Taew (Krabi province); 8, Jude (Trang province); 9, Lampeng (Trang province); 10, Khaowiset (Trang province); 11, Yon (Trang province); 12, Natam (Trang province), type locality of N. pseudomacronyx n.sp.; 13, Teang (Satun province); 14, Prayod (Songkla province); 15, Kangkao (Songkla province); 16, Kaekae (Pattani province); 17, Lankwai (Pattani province); 18, Kabae (Yala province); 19, Judedang (Narathiwas province); 20, Jae-son (Phuket province); 21, Jik (Phuket province); 22, Maikhao (Phuket province). 
be inferred from Tab. 1. Both are equally interesting, yet Natam contains a relatively high cryptic diversity, with Leydigiopsis sp. (Van Damme and Sinev, 2013), Guernella $\mathrm{cf}$ raphaelis and Grimaldina cf. brazzai. In total, Natam contained $c a$. two Bosminidae, 24 Chydoridae ( $57 \%$ of the total; including the two new species), four Daphniidae, two Moinidae, one ilyocryptid and five Sididae. The Chydoridae make up the largest group over the 22 swamp habitats together, about $66 \%$ of the total ( 48 out of 73 species), followed by the Macrothricidae (12\%; 9 species) and the Sididae (11\%; 8 species). Daphniidae make up only a small proportion in these sites $(5 \% ; 4$ species).

\section{DISCUSSION}

Systematics: on Karualona and Notoalona

Morphology of the new Karualona

Karualona serrulata n.sp. contains several interesting features that make it a conspicuous species in the genus: i) serrulated posteroventral valve corner (divided teeth); ii) postabdomen with thick marginal teeth on the postanal margin and a large basal spine on the terminal claw, as long as the claw thickness at the base; iii) first limb with a series of single setules on the anteroventral face of the limb corm; and iv) first limb with conspicuously thick conical seta on third endite. Of these four character states, the presence of single setules on the anterior margin of the first limb is the most remarkable feature. Within the Aloninae, this condition is only known in the Alona quadrangularis species group (Van Damme and Dumont, 2008) and in Leydigiopsis Sars, 1901 (Sinev, 2004), yet this is most certainly a homoplasy. In other limb characters, the species is not particular in the genus, except perhaps for the strongly thickened short seta on the third endite of the first limb, the function of which is unknown. The serrulated valve margin is not a spectacular character in itself, yet it allows a useful, quick recognition of the

Tab. 2. Sampling dates for the swamp sites investigated in Southern Thailand, listed in Tab. 1 and Fig. 11.

\begin{tabular}{|c|c|c|c|}
\hline Number & Name & Collecting dates & Symbol \\
\hline 1 & Nhongkla & September 1999; April 2000 & $\bigcirc$ \\
\hline 2 & Lum & September 1999; April 2001 & O \\
\hline 3 & Lein & September 1999; April 2002 & $O$ \\
\hline 4 & Kangkao & November 1999; May 2000 & O \\
\hline 5 & Thung-nongkwai & September 1999; April 2000 & O \\
\hline 6 & Swamp at Ratchaprapa dam & April 2010 & - \\
\hline 7 & Tiew & August and November 1999; February, May and August 2000 & $\mathrm{O}$ \\
\hline 8 & Jude & August and November 1999; February, May and August 2000 & $\bigcirc$ \\
\hline 9 & Lampeng & August and November 1999; February, May and August 2000 & $\mathrm{O}$ \\
\hline 10 & Khaowiset & August and November 1999; February, May and August 2000 & $\bigcirc$ \\
\hline 11 & Yon & August and November 1999; February, May and August 2000 & $\bigcirc$ \\
\hline 12 & Natam & August and November 1999; February, May and August 2000 & 粪 \\
\hline 13 & Tiang & November 1999; May 2000 & $\bigcirc$ \\
\hline 14 & Prayod & November 1999; May 2000 & $O$ \\
\hline 15 & Khangkao & July 2012 & $\bullet$ \\
\hline 16 & Kaekae & November 1999; May 2000 & O \\
\hline 17 & Lan-kwai & November 1999; May 2000 & O \\
\hline 18 & Kabae & November 1999; May 2000 & $\mathrm{O}$ \\
\hline 19 & Judedang & November 1999; May 2000 & $\bigcirc$ \\
\hline 20 & Jae-son & September 1999; April 2000 & $\bigcirc$ \\
\hline 21 & Jik & September 1999; April 2001 & O \\
\hline 22 & Maikhao & September 1999; April 2002; March 2010 & O \\
\hline
\end{tabular}


species, setting $K$. serrulata n.sp. apart from all other Karualona (which have the typical conical teeth in the posteroventral valve corner). Affinities of $K$. serrulata n.sp. within the genus are unclear, as the species is unusual. Large marginal teeth on the postabdomen for example, are typical for the New World species of Karualona, not for the Old World species. On the other hand, shape of the postabdomen and several limb characters, such as the exopodite setal arrangement of the fourth limb, lean towards $K$. iberica. These affinities do not necessarily indicate relationship or ancestry. They indicate that $K$. serrulata $n$.sp. is a clearly separate species in its own right, its morphology containing a mixture of unique and shared features. There can be no doubt however, that $K$. serrulata $\mathrm{n}$.sp. is morphologically not close to $K$. karua or its closest related forms. Sympatrically with K. serrulata n.sp., other populations of Karualona cf. karua occur (Fig. 9), but the identity of the latter is not clear, as discussed in the next section.

\section{What is the identity of the common Karualona in Southern Thailand?}

The description of Karualona serrulata n.sp. shows that there is more than one species of Karualona in SE Asia, yet the species have separate ecologies. K. serrulata n.sp. is found nearly exclusively in swamps. In contrast, other Karualona in the region occur in this habitat, yet are also found in lakes, ponds and even streams or rivers. In fact, Karualona is among the most common cladocerans in the region. But which other species of Karualona occur in SE Asia? Maiphae et al. $(2005,2008)$ list both $K$. iberica and K. karua in checklists from the region, but the identity of these forms is uncertain. The most common, widespread Karualona populations from S Thailand (Fig. 9) show several differences from the Australian (true) populations of Karualona karua, which is depicted in Alonso and Pretus (1989). The latter could indicate that these populations belong to a different species of the karua-complex. However, we are uncertain whether this comprises one highly variable species or a number of cryptic species. From the phenotypical variability of the parthenogenetic females, the situation of Karualona sp. in SE Asia seems nearly as complex as that of Alona rectangula Sars, 1962 (now Coronatella rectangula) in Europe, with a high variability and a number of intermediate forms that have lead to confused synonymy in the latter (Van Damme et al., 2010). We observed that the morphological variability in Karualona populations in S Thailand is considerable (Fig. 10), ranging in a few characters between the iberica-complex and the karua-complex. The extreme variability and unclear species boundaries might indicate local speciation and the existence of cryptic species in Karualona species complexes in SE Asia. It could also indicate hybridisation between karua- and iber- ica or even with other, yet undescribed species in Karualona.

The identity of Karualona sp. populations in SE Asia becomes even more complex if we consider nomenclature issues. Jiang (1963) described Alona kwangsiensis Jiang, 1963 from the Yujian river (Pearl river basin) in Nanning, the capital of the Guangxi Zhuan autonomous region, China. Venkataraman (1999; as Biapertura) used the species name in India, however kwangsiensis was synonymised with K. karua by Smirnov (1971; as Biapertura), confirmed by Dumont and Silva-Briano (2000; as Karualona). The description of Jiang (1963) is inadequate for evaluation and the main diagnostic character suggested by the author, i.e. the number of denticles on the posteroventral corner, is insufficient. However, considering the type locality of this taxon, we cannot rule out the possibility that Karualona kwangsiensis (Jiang, 1963) could be actually closer to the Thai $K$. cf. karua populations than the Australian populations. The taxon has also been reported from Laos (Kotov et al., 2013). The Guangxi Zhuan autonomous region is situated in the southern, subtropical part of China, and it is biogeographically part of the Oriental zone. If SE Asian populations of $K$. cf. karua would appear distinct from the Australian populations ( $K$. karua s.str.) in future studies, $K$. kwangsiensis should be taken into consideration for comparison. This, again, underlines the complexity of identifying and naming the chydorid populations in the region.

In fact, we are even unclear on the species boundaries of $K$. karua in Australia. In an online note of the Queensland Naturalist Club, Constantine (2006) raises the question if $K$. karua can be considered as a single species in Australia. The author points out that K. karua was originally described from Stroud, New South Wales (King, 1853) whereas the redescription of Dumont and Silva-Briano (2000) is based on specimens from Western Australia, and Alonso and Pretus (1989) examined specimens from Queensland, three localities that are quite far from each other in this huge continent with well-known regional endemism. We can observe some (e.g. limb 4 exopodite) morphological differences between the eastern population depicted by Alonso and Pretus (1989) and the western population in Dumont and Silva-Briano (2000), but it remains a fact that we do not know the phenotypical variability or the distribution of true K. karua in Australia, or of the related forms in SE Asia, and that nothing has been published so far about the genetics of this small lineage.

From a biogeographical point of view, the occurrence of the Mediterranean-African K. iberica and the Australian $K$. karua in SE Asia, or even both, is possible. A few cladocerans from the Old World, as well as several truly Australian taxa, occur in the Oriental Zone and can be found in Thailand (Maiphae et al., 2008; Sinev and Kotov, 2012; Korovchinsky, 2013). For some of the taxa that occur north 
of the Wallace line and meet taxa from the Old World, SE Asia acts as a mixing zone, and perhaps hybridization between congeners occurs. Is this the case for $K$. iberica and $K$. karua in Thailand or between $K$. karua and other, yet unknown species of the complex? It is unclear at this point. In any case, Karualona in SE Asia merits further study. We can say that the status is unclear, and that these populations, which might comprise more than one species, cannot be unambiguously assigned to either K. karua or K. iberica, with the variability laying somewhere in between. Only a comparative study of the male morphologies and a survey of molecular markers (e.g. mitochondrial and ribosomal genes), comparing $K$. iberica and $K$. karua populations from the terra typica with SE Asian populations, can help us delineate the Karualona species identities and -boundaries in the region. For now, we can say that the situation seems more complex than it was hitherto assumed and that it is impossible to comprehend from adult parthenogenetic female phenotypes alone. Molecular analysis of the southern Thai populations has now started (Maiphae, unpublished data) and will hopefully help to clarify the issue.

\section{Key to the adult parthenogenetic females of Karualona}

Based on the above, we aimed to adapt the key to Karualona and add a pictorial key, including K. serrulata n.sp. Our key builds on the diagnostic characters and keys by Alonso and Pretus (1989) for K. karua vs K. iberica, by Dumont and Silva-Briano (2000) for K. socotrana, by Sinev and Hollwedel (2005) for K. penuelasi versus $K$. muelleri, combined with new observations from this study, taking variability into account. Limb characters were not included as they are not feasible, nor practical, for separating K. iberica from K. karua, as suggested in the key of Dumont and Silva-Briano (2000). In particular, the scrapers of the second limb, a character for which we found many intermediate forms in Thailand, works for $K$. karua s.str. and $K$. iberica s.str., but it creates problems in SE Asia (which could comprise new species). Separating the New World species as in the key of Sinev and Hollwedel (2005) mainly based on head pore characters, is also not practical, especially because a lot of variability and intermediate forms exist in the $K$. cf. karua populations in SE Asia.

Though subject to variability (see Alonso and Pretus, 1989), postabdomen dimensions, in our opinion, seem a more stable diagnostic character for both taxa and were used here to separate the larger K. karua- and K. iberica species groups. Other characters in the key have been evaluated to include variability, for example in using marginal teeth on the postabdomen, where there is also a wide range of states between species (shown in the pictorial key) (Fig. 12) and the division in our key is aimed to be more nuanced than in Sinev and Hollwedel (2005) in order to avoid erroneous species identifications. We listed the regions where identifications have been confirmed in literature and the taxon's possible wider occurrence. For example, even though it is only reported from a few countries, it is likely that $K$. muelleri has a wider distribution in South America (Sinev and Hollwedel, 2005) and $K$. iberica in Africa (Alonso and Pretus, 1989; Dumont and Silva-Briano, 2000). It is unclear where the limit of distribution is in K. karua outside Australia, or of K. penuelasi outside Mexico. K. socotrana could be an endemic of the Indian Ocean island Socotra, but populations from East Africa and Arabia should be compared and the status is unknown. As stated above, the morphological boundaries between $K$. iberica and K. karua are unclear in the SE Asian populations, with intermediate forms. So, the key below only guides to the main groups of species, but within the $K$. iberica and $K$. karua-species complexes, still several cryptic species can be expected in the tropics of the Old World.

1. Compound eye present................................................2 Compound eye absent ................ alsafadii Dumont and Brancelj, 1994 Distribution: Yemen. Hypogean species.

2. Posteroventral corner of the valves with one to six single (mostly three), well-defined conical teeth ........... 3 Posteroventral corner of the valves serrulate, with subdivided teeth K. serrulata n.sp. Distribution: S Thailand, Vietnam

3. Postabdomen with embayment near the base of the tc. Basal spine on the terminal claw of the postabdomen mostly well developed (i.e. well visible, its length more than half of the claw thickness at the base and mostly longer, between 0.5-1.2 times this thickness). If the basal spine is shorter and less developed, as in some $K$. cf. karua populations, then there is still an embayment near the tc base and there is a space between the basal spine and the pecten) ....................... 4 No embayment near the base of the terminal claw. Basal spine on the terminal claw of the postabdomen not developed (i.e. hardly visible and hardly distinguishable from pecten, its length not more than one third of the claw thickness at the base). No space between the basal spine and the pecten (but a space between the basal spinules and the basal spine)

K. socotrana Dumont and Silva-Briano, 2000 Distribution: Socotra island (Yemen). Wider distribution in Africa and Middle East unknown.

4. Marginal teeth on the postanal margin of the postabdomen clear, strongly developed, (long conical, singular or with small adjacent denticles) ......................5 (New World species)

Marginal teeth on the postanal margin of the postabdomen different (i.e. small conical or fine in groups with long adjacent denticles)

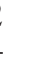


5. Distal spine in most lateral fascicles on the postanal part of the postabdomen not reaching beyond the margin. Marginal teeth relatively long. Antennal endopod with three terminal setae of similar thickness

K. penuelasi Dumont and ..Silva-Briano, 2000

Distribution: Mexico. Wider distribution in Neotropics unknown.

Distal spine in most lateral fascicles on the postanal part of the postabdomen reaching beyond the margin. Marginal teeth thicker. Antennal endopod with three terminal setae of which one clearly thicker than the other two K. muelleri (Richard, 1897) Distribution: Chile, Brazil (Neotropics).

6. Anal margin about as long as postanal margin. Preanal corner low, at the same level as the postanal corner

..K. iberica Alonso and Pretus, 1989 Distribution: Mediterranean, Northern Africa. Exact limits of distribution to south ( $E$ and $S$ Africa) and east (E and SE Asia) not well known. Anal margin 1.5-2 times as long as postanal margin. Preanal corner higher than the postanal corner

..K. karua (King, 1853) Australasian species complex, distribution unclear. Distribution Karualona karua s.str.: Australia. East and SE Asian populations of $K$. cf. karua remain to be revised.

\section{Notes on the genus Notoalona Rajapaksa and Frey, 1987}

Since the study of Rajapaksa and Fernando (1987), no new species has been described in the genus Notoalona. The new species, $N$. pseudomacronyx n.sp., cannot be confused with other species in the genus because of the peculiar, macronyx-like postabdomen. There is no relationship with Alona macronyx, a species recently redescribed and allocated to the genus Celsinotum Frey, 1991 (Sinev and Kotov, 2012). The postabdomen shape is purely a case of resemblance, as the genera Notoalona and Celsinotum belong to different branches in the Aloninae, as shown by their limb features. From all currently described species, $N$. pseudomacronyx n.sp. differs in having the deepest incisions in the headshield behind the rostrum for the genus, and having the longest basal claw with strong basal spines on the postabdomen. The fifth limb has three setae on the exopodite as in $N$. freyi, not four as in N. globulosa and it has only two setae on the first endite on limb 1 instead of three as in N. globulosa (not in freyi). On the postabdomen, the number of postanal denticles or denticle groups is 7-8 in N. pseudomacronyx n.sp., but it is always more than 11 (11-13) in both globulosa and freyi. The closest in morphology, is a currently undescribed African taxon of Notoalona.

In the description of the genus, Rajapaksa and Fer- nando (1987) depicted Notoalona globulosa specimens from Africa. These belong to populations from Tanzania and Ghana, yet cannot be named N. globulosa (to our opinion). In earlier notes the opinion by Rajapaksa and Fernando (1987) was followed (Van Damme et al., 2010), but the finding of $N$. pseudomacronyx $\mathrm{n}$.sp. raises doubts about the identity of the African populations. They most likely belong to another, undescribed species of Notoalona. Smirnov (1971) grouped African populations with the ones of Stingelin (from Saigon) under Indialona globulosa var. insulcata (Stingelin, 1905), an invalid move according to Rajapaksa and Fernando (1987). Also Dumont and Van de Velde (1977) named populations from Niger, after Smirnov, as I. globulosa insulcata. Regardless of the correct name, the African populations show i) a strong notch on the headshield, demarcating a truncated rostrum, ii) a long basal spine on the terminal claw, iii) a postanal margin of about two times the anal margin, the former of which has iv) about ten marginal denticles. The long basal spine is clearly depicted in Rey and Saint-Jean (1968) from lake Chad, the postabdomen and lateral fascicles in Dumont and Van de Velde (1977) from Niger, and the deep headshield notch in Smirnov (1971) from the White Nile. These character states are significant and shared with N. pseudomacronyx n.sp. They are not found in the East Asian populations of N. globulosa. The African populations need to be defined in comparison with these new findings, but it seems to merit a full species status. As the limb characters of $N$. pseudomacronyx n.sp. show a clear difference with $N$. globulosa s.str. (e.g. the absence of a seta on first and on fifth limb in comparison to $N$. globulosa), the above characters indicate more than only a variability. However, $N$. pseudomacronyx n.sp. differs from the African Notoalona sp. by being much smaller and having a more tapered postabdomen, among other characters shown in the species diagnosis and in the key. Until a revision of the related African populations, we can only say that at present, these two taxa seem to be each other's closest relatives within the genus.

The new Notoalona species conforms in limb characters with the other species in the genus, which has a number of synapomorphies in the Chydoridae. Notoalona truly has unusual limb features within the Cladocera. The limb characters and unique features were described in Rajapaksa and Fernando (1987), yet not discussed in detail (e.g. endites of limbs 3-4). Some additional observations on the peculiar characters of Notoalona are mentioned below.

Notoalona has a first antenna with a strong projection for the sensory seta, which is a condition more typical for the subfamily of the Chydorinae than for the Aloninae, yet this state occurs also for example in Leydigiopsis Sars, 1901 (Sinev, 2004) and in Tretocephala Frey, 1965. In all species of Notoalona, the first limb has anterior elements, 


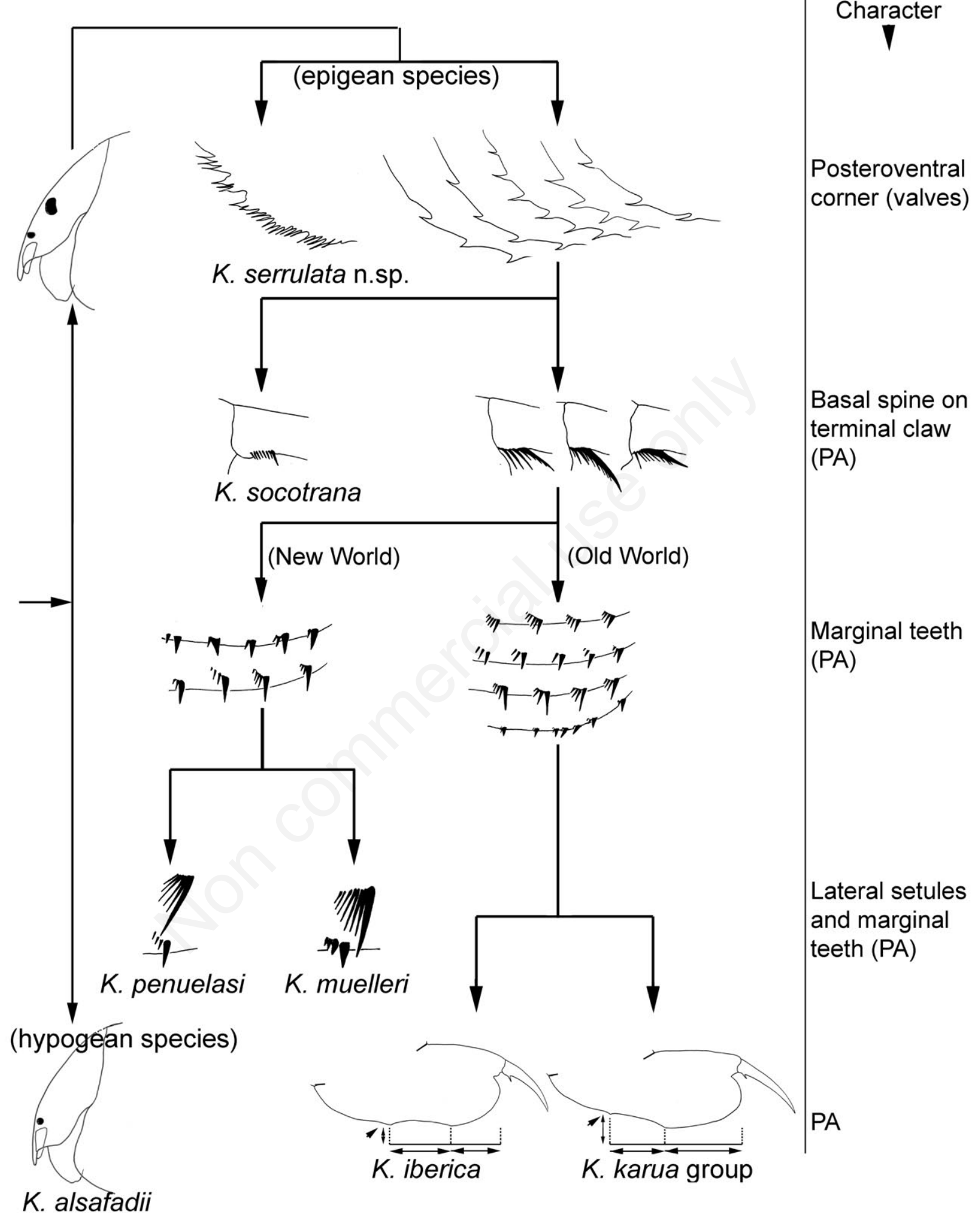

Fig. 12. Pictorial key to the adult parthenogenetic females of Karualona Dumont and Silva-Briano, 2000. The key includes K. serrulata n.sp. Characters and drawings build on the current and previous works (including scanning electron microscopy photographs), see Alonso and Pretus (1989), Dumont and Silva-Briano (2000), Sinev and Hollwedel (2005), Van Damme and Dumont (2010). The key is an update of existing keys, yet modified with new observations and taxa, see other keys in Dumont and Silva-Briano (2000), Alonso and Pretus (1989), and Sinev and Hollwedel (2005). Characters in the right column are for the epigean species. PA=postabdomen. 
of which one is a strongly modified seta, unique in the Chydoridae [branched seta in Rajapaksa and Fernando, (1987)]. This is a peculiar seta of which the function is unknown, and it reminds of the modified anterior setae named the Fryer's forks in the first limbs of Macrothricidae by Dumont and Silva-Briano (1998). This type of seta itself, with a bottle-like shape, a broad blunt tip and a merged group of setules that bend over the apex, is similar to the modified setae in the exopodites of the fourth limbs in the Aloninae Alonopsis and in the (hypo)rheic Nicsmirnovius and Phreatalona, but also here the function is unknown (Van Damme et al., 2009), and this is only a resemblance. The absence of anterior setule groups on the first limb in Notoalona is unique within the Chydoridae, normally there are groups of setules or single setules here. Also the gnathobase is well developed, which is unusual. The second limb is similar to most Aloninae, except that the three gnathobasic elements are on an elevated basis. This condition is relatively rare as well, and occurs for example in Tretocephala. The third limb has seven exopodite setae, the maximum number for Aloninae, of which the one closest to the epipodite is very long. The endopodite of the third limb has a full set of setae in the Aloninae, and all are well developed. This is the same for the epipodite in the fourth limb, where the flaming torch setae are not modified into short bottle-like structures. The latter is again an unusual condition, as the flaming torch setae are normally not as seta-like. In a few genera, like Leydigiopsis and Tretocephala, the flaming torch setae are elongate as well, not as modified as in the majority of the Aloninae. The exopodite of the fourth limb in Notoalona is highly peculiar in that the exopodite setae have a $3+3$ arrangement, the three setae closest to the endopodite joined on a separate elevated basis (incision between this basis and the rest of the limb). This condition is unknown in other Aloninae. The absence of a fourth seta on the exopodite of the fifth limb is another highly unusual feature that it occurs not in all Notoalona species (not in N. globulosa) and is only found in Indialona and Spinalona (Kotov, 2000). In particular the anterior modified seta and the absence of setule groups on the first limb, the arrangement of the exopodite setae of the fourth limb, the nonmodified flaming torch setae and the absence of an exopodite seta in the fifth limb (not all species), are truly peculiar characters for Notoalona.

In addition to the appendage character states, Notoalona also has a special set of head pores and has submarginal valve setae (the former unique in the Cladocera, the latter unique in the Aloninae; Rajapaksa and Fernando, 1987) and a low sexual dimorphism in the postabdomen. Therefore, Notoalona is one of the Aloninae of which the relationship with other genera is not easy to trace. Some similarities exist with a few other peculiar genera (Van Damme and Maiphae, 2013). As the species of this genus in general do not have an unusual ecology, the unusual characters can be an indication of ancestry instead of a particular adaptation to a niche, which should be further explored. Notoalona is no doubt a peculiar stenothermic lineage that might have split early in the Chydoridae, deriving from a stenothermic ancestor, with a few remaining taxa today, which show a typical intercontinental speciation.

\section{Key to the adult parthenogenetic females of Notoalona Rajapaksa and Fernando, 1987}

Our key (Fig. 13) is built on that of Rajapaksa and Fernando (1987), with the addition of a few characters of $N$. pseudomacronyx $\mathrm{n}$.sp. and Notoalona sp. from Africa, the latter of which we listed separate from N. globulosa. The key includes two yet unresolved species complexes in the circumtropics: the N. globulosa complex and the N. freyicomplex. South East Asian populations of $N$. cf. freyi, for example, should be revised in detail and compared to $N$. freyi s.str. (New World). Most uncertain identifications will fall in one of these two species complexes. For additional differences between freyi and globulosa, we refer to the table in Rajapaksa and Fernando (1987).

1. Notch on the headshield present ................................. Notch on the headshield absent ....Notoalona sculpta (Sars, 1901) Distribution: Brazil (Neotropics)

2. Postanal margin long in comparison to the anal margin (more than 2.5 times anal margin). Basal spine 1-1.5 times the width of the terminal claw at its basis and about $1 / 4-1 / 6^{\text {th }}$ of the terminal claw length. Postanal denticles (or denticle groups) 11-13 . .3 Postanal margin shorter (up to two times anal margin). Basal spine long, over two times width of terminal claw at its basis and about $1 / 3-1 / 4^{\text {th }}$ of the terminal claw length. Postanal denticles (or denticle groups) 7-11 ...4

3. Rostrum truncated. Preanal margin longer than anal margin. Postanal margin curved and with indistinct postanal corner. Basal spine short, not more than terminal claw at basis (about $1 / 5-1 / 6^{\text {th }}$ of terminal claw length) ...............Notoalona globulosa (Daday, 1898) Species complex with circumtropical distribution (Afrotropics, Neotropics, Oriental).

Distribution N. globulosa s.str.: E and SE Asia. Two subspecies in Australasia ......................................5 Rostrum rounded. Preanal margin shorter than or the same length as anal margin. Postanal margin straight and long and with distinct postanal corner. Basal spine longer $\left(1 / 4^{\text {th }}\right.$ of terminal claw length), more than terminal claw at basis .........Notoalona freyi Rajapaksa and Fernando, 1987

Most likely species complex with circumtropical distribution (Afrotropics, Neotropics, Oriental). Distribution $N$. freyi s.str.: S Nearctic (Florida), Neotropics. 
4. Basal spinules on terminal claw well developed, long and reaching half the basal spine length. Lateral fascicles in postanal portion six to ten groups. Small species, not more than $0.31 \mathrm{~mm}$ long.........Notoalona pseudomacronyx n.sp.

\section{Distribution: S Thailand.}

Basal spinules on terminal claw not reaching half the basal spine length. Lateral fascicles in postanal portion 11-14 groups. Larger species, 0.4-0.45 mm long

Notoalona sp.

\section{Distribution: Africa.}

5. Basal spine very short, about one sixth of terminal claw length. Terminal claw with proximal and distal pecten of similar lengths. Carapace with indistinct longitudinal lines ...........Notoalona globulosa globulosa (Daday, 1898)

Distribution: E and SE Asia.

Basal spine longer, about one fifth of terminal claw length. Terminal claw with proximal pecten distinctly larger than distal pecten, and with strong distal spine in proximal pecten. Carapace with three distinct longitudinal lines .....Notoalona globulosa australiensis Rajapaksa and Fernando, 1987

Distribution: Australia.

\section{On Cladocera in South East Asian swamps}

\section{Swamps in South East Asia contain high Cladocera richness}

Our case study illustrates that inland swamps in the lowlands of S Thailand contain a hidden diversity of Cladocera. The total taxon number counted during our preliminary survey (73 taxa; Tab. 1) adds up to about $85 \%$ of the total number of cladoceran taxa currently known from S Thailand and ca. $68 \%$ of the total number found in the country. Sa-ardrit (2002) mentioned earlier, during a preliminary survey of the Cladocera from Trang province, that out of 19 lentic sites examined, the species richness found in alluvial swamps was highest ( 57 species from seven sites), followed by permanent peat swamps (51 species from three sites) and dams (39 species from three sites). Of all sites and habitats examined (both lentic and lotic) by Sa-ardrit (2002), the highest species richness in Trang province was found in Yon peat swamp (43 spp.), followed by Natam swamp (41 spp.) and Khaowiset peat swamp (38 spp.). We cannot conclude at this point that the relative species richness is higher in swamps when compared to other freshwater habitats, as this would require more systematic surveys and statistics, with standardised sampling. However, it is clear that swamps in $\mathrm{S}$ Thailand and likely in the whole of SE Asia, maintain a high cladoceran richness that contains a large proportion of the total species number. Several species would be missed when sampling only the pelagic of lakes, which is the focus of most zooplankton surveys. In fact, it is clear that the proportion of pelagic/planktonic species such as Daphniidae is very low when compared to the littoral/benthic species such as the Chydoridae. Even though the latter is in general the most speciose group, the absence of a well-developed pelagic zone and the dominance of littoral/benthic microhabitats, favours chydorids over daphniids. Specific sampling campaigns, oriented at swamp habitats, would undoubtedly reveal more taxa.

The three swamp sites where we encountered Karualona serrulata n.sp. (Fig. 14), are relatively similar: Natam swamp (Fig. 14A and 14B), a small swamp at Ratchaprapa dam (Fig. 14C) and Kangkao swamp (Fig. 14C). These are easily recognizable habitats, often covered in Salvinia cucullata and with dark (often orangebrown) water color (hence black waters vs white waters in the Neotropics) due to humic acids. This type of habitats is rapidly disappearing in SE Asia, under pressure of infrastructure development or by changes in the water table due to human-induced changes in the alluvial source, or simply dredging and building. However, containing peculiar species, swamps are worth studying in the region. In rotifers, more than half of the Thai fauna was found in peat swamps, several of which are endemic, not only to the habitat, but also to $\mathrm{S}$ Thailand (Chittapun et al., 2007). Swamps are among the marginal habitats, such as temporary pools, ancient habitats which have played an underestimated role in cladoceran evolution.

Although the total tally of cladoceran species in Thailand has strongly increased in the last decade due to more intense surveys and an increase in taxonomical efforts, the number of new records and new species still increase with surveys of new habitats. There are highly diverse habitats in SE Asia that remain to be explored in areas that were never sampled, especially in peninsular Thailand. Surveys that distinguish between the different swamp types still remain to be carried out. As they constitute different habitats with specific histories and ecologies (Morley, 2000; Morley and Morley, 2013), the various swamp types are likely to harbour different cladoceran communities. For example, Alona sarasinorum, was found in Kaekae peat swamp in Pattani province (Tab. 1), which is one of the very few chydorid species that can be found in brackish conditions (Van Damme and Maiphae, 2013). The alluvial swamps include a large number of pond-dwelling taxa, as well as true paludal taxa. Many belong to the littoral-benthic chydorids and include for example Celsinotum macronyx, a species that is extremely rare in S Thailand, yet it is found in swamps (Tab. 1). Even riverine taxa can be found (e.g. Nicsmirnovius eximius), suggesting sites with hyporheic inflow and therefore with active alluvial connections, at least during certain periods of the year. New species are present, as shown in this study and some have distinctive morphologies, like the paludal Karualona serrulata n.sp., Notoalona 


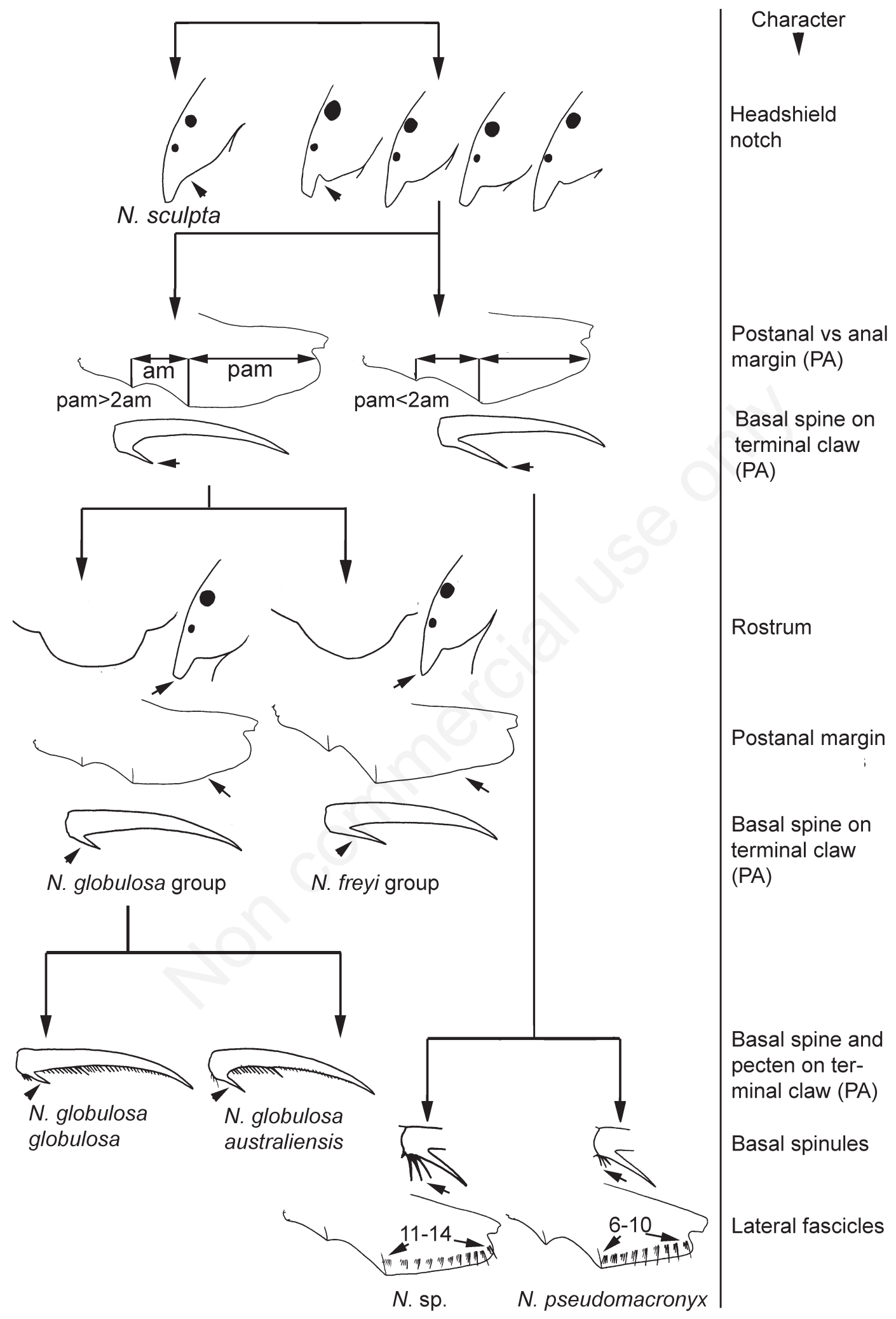

Fig. 13. Pictorial key to the adult parthenogenetic females of Notoalona Rajapaksa and Fernando, 1987. The key is modified after Rajapaksa and Fernando (1987) and includes N. pseudomacronyx n.sp. from Southern Thailand and the unrevised Notoalona sp. from Africa. Drawings of structures for $N$. freyi and $N$. globulosa are simplified from Rajapaksa and Fernando (1987). am=anal margin; pam=postanal margin; $\mathrm{PA}=$ postabdomen. 

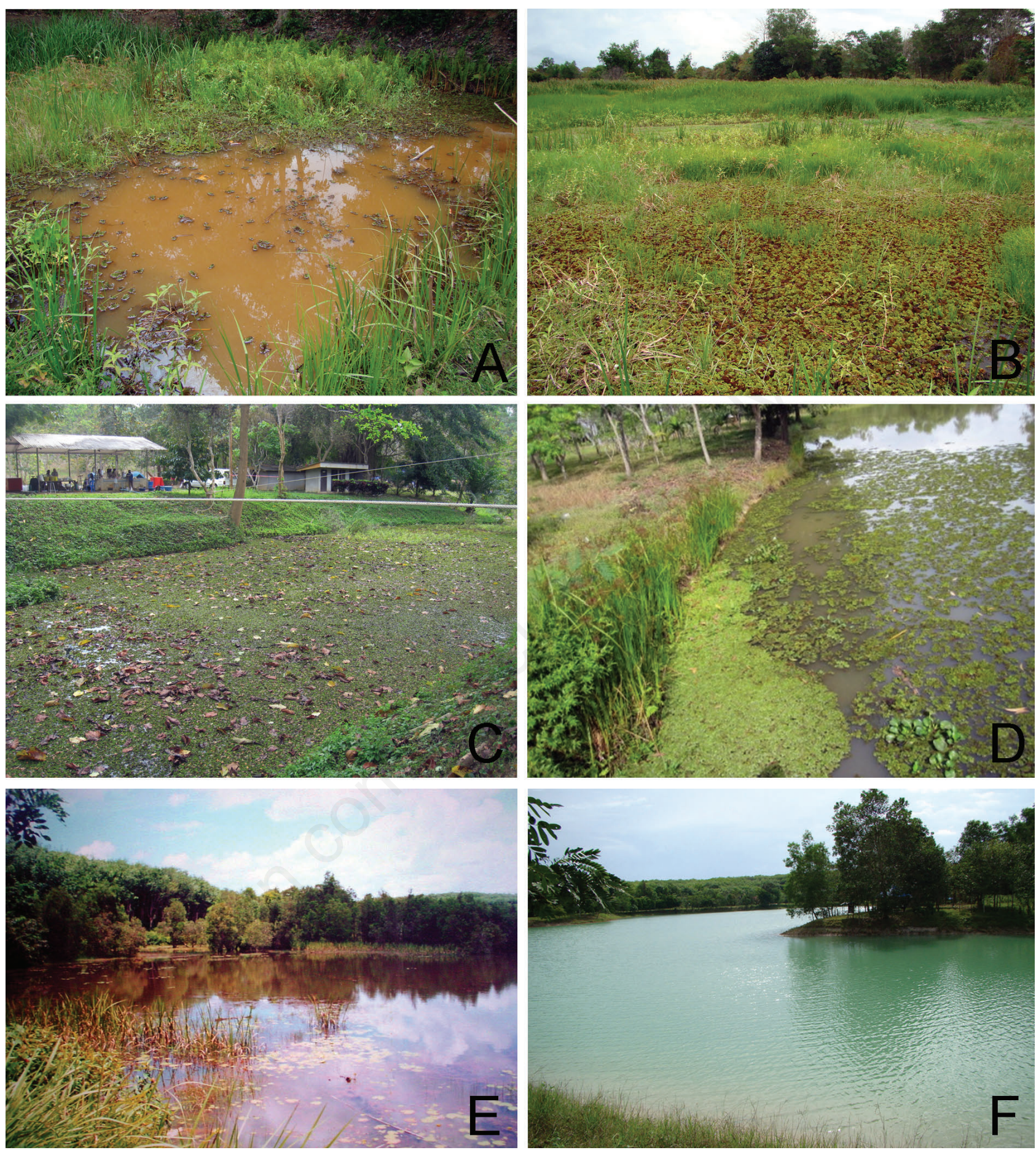

Fig. 14. A-D) The localities in Southern Thailand where Karualona serrulata n.sp. (A-D) and Notoalona pseudomacronyx n.sp. (AB) were found. Photographs (A-D) were taken in 2010-2012. E,F) Show an example of swamps as rapidly changing habitats: Yon peat swamp, Trang province in 2004 (E) vs 2011 (F). A,B) Natam swamp, the second most diverse site for cladocerans in Trang province and type locality of $N$. pseudomacronyx $\mathrm{n}$.sp. Also K. serrulata n.sp. and Leydigiopsis sp. occur here [for the latter, see Van Damme and Sinev (2013)]; C) swamp at Ratchaprapa dam, Suratthani province, type locality of K. serrulata n.sp; D) Kangkao peat swamp, Songkhla province; E) Yon peat swamp, Trang province, in 2004, rich in macrophytes and Cladocera; F) Yon peat swamp, Trang province, photographed from approximately the same area as in (E) but seven years later, in 2011. The site is no longer a shallow peat swamp and the littoral and floating vegetation, as well as the diversity of Cladocera, have disappeared. See also Fig. 11 for the location of these sites on the map. 
pseudomacronyx n.sp. (this study) and Leydigiopsis sp. (Van Damme and Sinev, 2013). They could be ancient species, that evolved in swamp ecosystems when the habitat covered much larger areas in SE Asia (Cenozoic; Morley and Morley, 2013). However, on top of these obvious new species, a significant cryptic diversity can be expected among the swamp-inhabiting taxa that belong to widespread species complexes that are in need of taxonomical revision. These include, for example, Grimaldina cf. brazzai, Guernella cf. raphaelis, Streblocerus cf. pygmaeus and Alonella cf. nana (note that such cryptic diversity in species groups is not limited to swamps only, but that it is general for cladocerans in Thailand or even SE Asia; Maiphae et al., 2008; Korovchinsky, 2013). New records can be found in swamps as well. Sarsilatona papuana Daday, 1900 is a new record for Thailand (Choedchim; Maiphae et al., unpublished data) that has been found in Maikhao peat swamp (Phuket island) in 2011, even though this locality has been surveyed repeatedly in the years before. It is not surprising that new species have been found in swamps, and that more should be expected, among the richest cladoceran families. The proportions of species richness per family in the swamp habitats is similar when compared with Maiphae et al. (2008) for Thailand (Chydoridae being relatively the richest group, followed by Macrothricidae and Sididae). However, Chydoridae seem to make up a bit more, $c a$. 66\% of the swamp taxa (Tab. 1), compared with $60 \%$ of the total taxa in Thailand ( 60 out of 99 species; after Maiphae et al., 2008), which could be related to an underestimation of the shallow, littoral habitats in general surveys. swamps are rich in detritus and in macrophytes, which makes them an ideal place for a number of different chydorids to thrive in. The species numbers have to be read here with a strong critical remark, i.e. that even in a region that is well sampled and taxonomically up to date such as Thailand, many cladoceran records remain provisional until detailed revisions have been carried out.

Acting as potential refuges from predators and as ancient relict habitats, swamps could even be more interesting for cladocerans than we currently think. Some of the species we find right now in these tropical habitats, might have evolved in them even before continental connections were lost. We find a similar set of cladoceran taxa in swamp habitats in other continents, which could suggest that lowland swamps in tropical and subtropical regions once stretched significantly wider and now leave a fragmented habitat with similar species in the Afrotropics, Neotropics and the Oriental zone. Thomas (1961) found Guernella raphaelis and Grimaldina brazzai in swamps in Uganda, along with several other taxa that bear the same names (yet are not necessarily the same species) of those recorded here in the swamps of S Thailand. The same can be said for the Neotropical swamps, where species like Macrothrix sioli Smirnov, 1982 or Leydigiop- sis curvirostris Sars, 1901 are replaced by close siblings such as M. pholpunthini or Leydigiopsis sp. [Van Damme and Sinev (2013) on these S American-SE Asian connections]. These are not common species, but animals that are well adapted to this particular habitat, and in most cases to larger temporary systems.

Many of these localities, like Yon and Natam, which are the most species-rich cladoceran sites currently known in Trang province (Sa-ardrit, 2002), have been drastically transformed over the last decade, as a result of human impact (Fig. 14E and 14F). Most of these localities were sampled in 1999-2000, and their species composition may have changed significantly. However, we think it is important to show the existing data, as a reference for the future. In Yon peat swamp, we only found a dominance of Bosminidae during a short visit in 2010 (Fig. 14F), but swamp communities could be retrieved in a very small remaining patch of swamp nearby the site (however, on private property), as the habitat for these species was reduced to a tiny fragment of its former condition. Also on Phuket, large swamps undergo the same fate and important species are found that may be lost (Van Damme and Maiphae, 2013). Many of the current-day swamps in developed areas of SE Asia are already largely remnants of forest peat swamps after deforestation that took place decades, sometimes centuries, ago. On top of that, urban expansion (road construction, etc.), pollution and changes in the hydrological table and active dredging, further effect the quality of all types of swamp habitats in the region. Such changes are, of course, inevitable. However, it is important to record the existing diversity before the lowland swamps, as important habitats for zooplankton richness, disappear completely. Undoubtedly, the loss of such habitats will have an effect on other aquatic biota as well, of which the diversity may be underestimated. The cladocerans form just one example.

In sum, from the above, we can conclude that swamps in SE Asia are rich in cladoceran species. Up to $85 \%$ of the local (S Thai) cladoceran fauna can be found in these habitats (from alluvial to brackish). Tropical (peat) swamps harbour rare cladoceran species, hidden cladoceran diversities, and can be considered as hotspots of cladoceran diversity. Also, the cryptic diversity includes true paludal taxa with conspicuous morphologies that have been largely ignored because of the lack of systematic studies for this habitat (for cladocerans), as well as representatives of widespread species groups that remain to be revised. Peat swamps are disappearing in the region, though their diversities are not yet well understood and they might contain specific endemics.

\section{CONCLUSIONS}

Inland swamps in SE Asia contain significant and hidden diversities in the Cladocera. A systematic in-depth survey of these habitats remains to be done and many tax- 
onomical issues are unresolved. Our description of two new Chydoridae from inland swamps in S Thailand illustrates the importance of sampling a wide range of freshwater habitats in tropical surveys (not just lakes and reservoirs) and the necessity of a high taxonomical resolution. Notoalona pseudomacronyx n.sp. and Karualona serrulata n.sp. are two new chydorid taxa from this habitat, showing a clear morphological divergence from other species within their genera. Other Karualona populations in S Thailand, which sometimes show intermediate morphologies between $K$. karua and K. iberica, indicate that there are still unresolved issues in the identity of the common SE Asian populations in these species complexes. Cryptic speciation, species boundaries and hybridisation in the Karualona populations of SE Asia should be further explored. Finally, swamp habitats are under development pressure and risk disappearing before their diversities have been explored. We have no doubt that surveys of swamps and other overlooked freshwater habitats in SE Asia will reveal more cladoceran species for the region.

\section{ACKNOWLEDGMENTS}

Supiyanit Maiphae would like to thank Associate Professor Pornsilp Pholpunthin, Department of Biology, Prince of Songkla University for his valuable advice and support throughout this research. This work was financially supported by the Thailand Research Fund (MRG5280030), the Higher Education Research Promotion, the National Research University Project of Thailand, Office of the Higher Education Commision of Thailand and the Plant Genetic Conservation Project. Mrs. Supaporn Fangcholjit, Faculty of Science and Technology [Prince of Songkla University (PSU)] is thanked for her co-operation in the Plant Genetic Conservation Project at Ratchaprapa dam. Phannee Sa-ardrit is most grateful to the Biodiversity Research and Training Program (BRT) and Graduate School, PSU, for financial support during the study of Cladocera in Trang province. Kay Van Damme thanks the Algal and Plankton Society of Thailand for his study visit to PSU in 2010, to Dr. Pornsilp Pholpunthin for facilitating this research at the Zooplankton Unit at PSU, and to Drs. La-orsri Sanoamuang and Maria K. Hołyńska for the invitation to the FISA Workshop in Maha Sarakham University, Thailand, 2012, which stimulated the completion of this paper. Also thanks goes to Dr. Artem Y. Sinev for sharing his notes on Vietnam on the presence of the new Karualona species and for reviewing this manuscript, as well as to Drs. Aleksey A. Kotov and Miguel Alonso for providing constructive notes during the review. Dr. Alonso mentioned during the revision of this paper that This kind of humble ecosystems are extraordinarily diverse and treasure the major part of known species and also many unknown species in the world - we wholeheartedly agree.

\section{REFERENCES}

Alonso M, Pretus JL, 1989. Alona iberica, new species: first evidence of noncosmopolitanism within the $A$. karua complex (Cladocera: Chydoridae). J. Crustacean Biol. 9:453-476.

Boonsom J, 1984. The freshwater zooplankton of Thailand (Rotifera and Crustacea). Hydrobiologia 113:223-229.

Chittapun S, Pholpunthin P, 2001. The rotifer fauna of peatswamps in southern Thailand. Hydrobiologia 446/447:255259.

Chittapun S, Pholpunthin P, Segers H, 1999. Rotifera from Peatswamps in Puket province, Thailand, with the Description of a new Colurella Bory de St. Vincent. Int. Rev. Hydrobiol. 84:587-593.

Chittapun S, Pholpunthin P, Segers H, 2002. Rotifer diversity in a peat-swamp in southern Thailand (Narathiwas province) with the description of a new species of Keratella Bory de St. Vincent. Ann. Limnol.-Int. J. Lim. 38:185-190.

Chittapun S, Pholpunthin P, Segers H, 2003. Contributions to the knowledge of Thai microfauna diversity: notes on rare peat swamp Rotifera, with the description of a new Lecane Nitzsch, 1872. Hydrobiologia 501:7-12.

Chittapun S, Pholpunthin P, Segers H, 2007. Diversity of rotifer fauna from five coastal peat swamps on Phuket island, Southern Thailand. ScienceAsia 33:383-387.

Conway KW, Kottelat M, 2011. Boraras naevus, a new species of miniature and sexually dichromatic freshwater fish from peninsular Thailand (Ostariophysi: Cyprinidae). Zootaxa 3002:45-51.

Dodson SI, Frey DG, 1991. Cladocera and other Branchiopoda, p. 723-786. In: J.H. Thorp and A.P. Covich (eds.), Ecology and classification of North American freshwater invertebrates. Academic Press.

Dumont HJ, Brancelj A, 1994. Alona alsafadii n.sp. from Yemen, a primitive, groundwater-dwelling member of the A. karua-group. Hydrobiologia 281:57-64.

Dumont HJ, Silva-Briano M, 1998. A reclassification of the anomopod families Macrotrichidae and Chydoridae, with the creation of a new suborder, the Radopoda (Crustacea: Branchiopoda). Hydrobiologia 384:29-36.

Dumont HJ, Silva-Briano M, 2000. Karualona n.gen. (Anomopoda: Chydoridae), with a description of two new species, and a key to all known species. Hydrobiologia 435:61-82.

Dumont HJ, Van de Velde I, 1977. [Cladocères et Conchostracés récoltés par le professeur Th. Monod dans la moyenne vallée du Niger en décembre 1972 et janvier 1973]. [Article in French]. Bull. de 1'I.F.A.N.T. 39:75-93.

Frey DG, 1993. The penetration of cladocerans into saline waters. Hydrobiologia 267:233-248.

Forró L, Korovchinsky NM, Kotov AA, Petrusek A, 2008. Global diversity of cladocerans (Cladocera: Crustacea) in freshwater. Hydrobiologia 595:177-184.

Jiang X, 1963. Description of two new species of Chinese Freshwater Cladocera with notes on four new records (Chinese, with English summary). Acta Zool. Sinica 15:255-262.

King R, 1853. On Australian Entomostraca. Pap. proc. R. Soc. Tasmania 2:253-263.

Korovchinsky NM, 2013. Cladocera (Crustacea: Branchiopoda) of South East Asia: history of explorations, taxon richness and notes on zoogeography. J. Limnol. 72(Suppl.2):e7. 
Kotov AA, 2000. Redescription and assignment of the chydorid Indialona ganapati Petkovski, 1966 (Branchiopoda: Anomopoda: Aloninae) to Indialonini, new tribus. Hydrobiologia 439:161-178.

Kotov AA, Maiphae S, Sanoamuang L, 2005. Revision of Macrothrix paulensis-like species (Anomopoda, Cladocera, Branchiopoda) in Asia, and phylogeny of the paulensisgroup. Arch. Hydrobiol. Suppl. Monogr. Stud. 151:269-299.

Kotov AA, Van Damme K, Bekker EI, Siboualipha S, Silva-Briano M, Adabache Ortiz A, Galván de la Rosa R, Sanoamuang L, 2013. Cladocera (Crustacea: Branchiopoda) of Vientiane province and municipality, Laos. J. Limnol. 72(Suppl.2):e6.

Maiphae S, Pholpunthin P, Dumont HJ, 2005. Species richness of the Cladocera (Branchiopoda: Anomopoda and Ctenopoda) in southern Thailand, and its complementarity with neighboring regions. Hydrobiologia 537:147-156.

Maiphae S, Pholpunthin P, Dumont HJ, 2008. Taxon richness and biogeography of the Cladocera (Crustacea, Ctenopoda, Anomopoda) of Thailand. Ann. Limnol.-Int. J. Lim. 44:33-43.

Morley RJ, 2000. Origin and evolution of tropical rain forests. John Wiley and Sons Ltd., Chichester: 362 pp.

Morley RJ, Morley HP, 2013. Mid Cenozoic freshwater wetlands of the Sunda region. J. Limnol. 72(Suppl.2):e2.

Rajapaksa R, Fernando CH, 1987. Redescription and assignment of Alona globulosa Daday, 1898 to a new genus Notoalona and a description of Notoalona freyi sp. nov. Hydrobiologia 144:131-153.

Rey J, Saint-Jean L, 1968. [Les Cladocères (Crustacés, Branchiopodes) du Tchad (première note)]. [Article in French]. Cah. ORSTOM Hydrobiol. 11:79-118.

Rogers DC, Thaimuangphol W, Saengphan N, Sanoamuang L, 2013. Current knowledge of the South East Asian large branchiopod Crustacea (Anostraca, Notostraca, Laevicaudata, Spinicaudata, Cyclestherida). J. Limnol. 72(Suppl.2):e5.

Sa-ardrit P, 2002. [Diversity and distribution of freshwater Cladocera in Trang province]. [Degree Thesis in Thai]. Prince of Songkla University ed., Thailand.

Sanoamuang L, 1998. Contributions to the knowledge of the Cladocera of northeast Thailand. Hydrobiologia 362: 45-53.

Sinev AY, 2004. Redescription of two species of the genus Leydigiopsis Sars, 1901 (Branchiopoda, Anomopoda, Chydoridae). Invertebrate Zoology 1:75-92. Available from: http://www.nature.air.ru/invertebrates/pdf_files/sinev_04_1.pdf

Sinev AY, 2009. Discrimination between two sibling species of Acroperus (Baird, 1843) from the Palearctic (Cladocera: Anomopoda: Chydoridae). Zootaxa 2176:1-21.

Sinev AY, Hollwedel W, 2005. Translocation of Alona muelleri Richard, 1897 into the genus Karualona Dumont \& Silva-
Briano, 2000 (Branchiopoda: Anomopoda: Chydoridae). Arthropoda Sel. 14:93-101.

Sinev AY, Korovchinsky NM, 2013. Cladocera (Crustacea: Branchiopoda) of Cat Tien National Park, South Vietnam. J. Limnol. 72(Suppl.2):e8.

Sinev AY, Kotov AA, 2012. New and rare Aloninae (Cladocera: Anomopoda: Chydoridae) from Indochina. Zootaxa 3334:1-28.

Sinev AY, Sanoamuang L, 2011. Hormonal induction of males as a method for studying tropical cladocerans: description of males of four chydorid species (Cladocera: Anomopoda: Chydoridae). Zootaxa 2826:45-56.

Smirnov NN, 1971. Chydoridae of the world. Israel Program for Scientific Translations, Jerusalem. Nauka, Leningrad: 531 pp.

Smirnov NN, 1996. The Chydorinae and Sayciinae (Chydoridae) of the world. Guides to the identification of the microinvertebrates of the continental waters of the world, vol. 11. SPB Academic Publ., Amsterdam: 197 pp.

Smirnov NN, 2008. Check-list of the South-African Cladocera (Crustacea: Branchiopoda). Zootaxa 1788:46-57.

Thomas IF, 1961. The Cladocera of the swamps of Uganda. Crustaceana 2:108-125.

Van Damme K, Brancelj A, Dumont HJ, 2009. Adaptations to the hyporheic in Aloninae (Crustacea: Cladocera): allocation of Alona protzi Hartwig, 1900 and related species to Phreatalona gen.nov. Hydrobiologia 618:1-34.

Van Damme K, Dumont HJ, 2008. The 'true' genus Alona Baird, 1843 (Crustacea: Cladocera: Anomopoda): characters of the A. quadrangularis-group and description of a new species from Democratic Republic Congo. Zootaxa 1945:1-25.

Van Damme K, Dumont HJ, 2010. Cladocera of the Lençóis Maranhenses (NE - Brazil): faunal composition and a reappraisal of Sars' Method. Braz. J. Biol. 70:755-779.

Van Damme K, Kotov AA, Dumont HJ, 2010. A checklist of names in Alona Baird 1843 (Crustacea: Cladocera: Chydoridae) and their current status: an analysis of the taxonomy of a lump genus. Zootaxa 2330:1-63.

Van Damme K, Maiphae S, 2013. Salinalona gen.nov., an euryhaline chydorid lineage (Crustacea: Branchiopoda: Cladocera: Anomopoda) from the Oriental region. J. Limnol. 72(Suppl.2):e9.

Van Damme K, Sinev AY, 2013. Tropical Amphi-Pacific disjunctions in the Cladocera (Crustacea: Branchiopoda). J. Limnol. 72(Suppl.2):e11.

Van Damme K, Sinev AY, Dumont HJ, 2011. Separation of Anthalona gen.n. from Alona Baird, 1843 (Branchiopoda: Cladocera: Anomopoda): morphology and evolution of scraping stenothermic alonines. Zootaxa 2875:1-64.

Venkataraman K, 1999. Resurrection of Biapertura kwangsiensis (Chiang 1963) from Biapertura karua (King 1853) (Crustacea: Cladocera). J. Bomb. Nat. Hist. Soc. 96:347-353. 